Yıl: 2021, Cilt: 54, Sayl: 2, 391-430

DOI: 10.30964/auebfd.690366, E-ISSN: 2458-8342, P-ISSN: 1301-3718

\title{
Okul Öncesi Öğretmenlerinin Meslek Yaşantılarının İlk Yıllarına İlişkin Anlatıları ${ }^{1}$
}

\begin{tabular}{cccc}
\hline MAKALE TÜRÜ & Başvuru Tarihi & Kabul Tarihi & Yayım Tarihi \\
Araştırma Makalesi & 18.02 .2020 & 10.04 .2021 & 06.05 .2021 \\
\hline İpek Özbay Karlıdă (D) & 2 ve Mehmet Sağlam & (iD & $\mathbf{3}$ \\
& Yozgat Bozok Üniversitesi &
\end{tabular}

\section{Öz}

$\mathrm{Bu}$ araştırma, okul öncesi öğretmenlerinin meslek yaşantılarının ilk yıllarına (1-3 yıl) ilişkin anlatılarını kapsamaktadır. Bu bağlamda araştırmanın amacı okul öncesi öğretmenlerinin meslek yaşantılarının ilk yıllarında yaşadıkları sorunlara ve bu sorunlara yönelik geliştirdikleri stratejilere yönelik hatırladıklarını ortaya çıkarmaktır. Araştırmanın yöntemini sözlü tarih yöntemi oluşturmaktadır. Araştırmanın verilerini sözlü tarih yöntemine göre gerçekleştirilen yarı-yapılandırılmış görüşmelerle derlenmiş sözlü anlatılar oluşturmaktadır. Araştırmanın çalışma grubunda amaçsal örnekleme yoluyla seçilmiş 20 okul öncesi öğretmeni bulunmaktadır. Ses kaydı alınan her bir görüşmenin çözümlenmesinden elde edilen veriler, içerik analizi yöntemi ile araştırmanın amacı bağlamında kategorilere ayrılarak analiz edilmiştir. Araştırma sonucunda öğretmenlerin lisans öğrenimlerinin son yılında geleceğe yönelik beklentilerinin öncelikli olarak Milli Eğitim Bakanlı̆̆ı'nda devlet okuluna kadrolu ögretmen olarak mesleğe atanmak olduğu ve çocukların gelişimine uygun nitelikli bir eğitim sunabilen öğretmenler olmayı arzuladıkları görülmüştür. Öğretmenlerin mesleğe başladıkları ilk yılın başında çoğunlukla mutluluk, heyecan ve tedirginlik duygularını yaşadıkları görülmekle birlikte hayal kırıklığı, korku, stres ve umutsuzluk duygularını da yaşadıkları bulunmuştur. Öğretmenlerin mesleğe ilk başladıklarında yaşadıkları sorunlar incelendiğinde ise bu sorunların çok çeşitli olduğu görülmüştür. Öğretmenlerin yaşadıkları bu sorunların çoğunlukla fiziksel ortam ve öğretmenlik meslek becerileri ile ilgili sorunlar olduğu görülürken, meslektaşları ve okul yönetimi ile daha az sorun yaşadıkları bulunmuştur. Öğretmenlerin ilk yılki mesleki yaşantılarının onların mesleki gelişimine katkısı ise özellikle veli ile etkili iletişim kurabilme konusunda olduğu görülmüştür.

Anahtar sözcükler: Okul öncesi öğretmenleri, sözlü tarih, mesleki deneyim, mesleki yaşantı, anlati.

Etik Kurul Kararı: Bu araştırma, 01.01.2020 tarihinden önce yapıldı̆̆ için etik kurul kararı zorunluluğu taşımamaktadır.

\footnotetext{
${ }^{1} \mathrm{Bu}$ araştırma makalesi 19-22 Haziran 2019 tarih aralığında Ankara Üniversitesi'nde düzenlenen $\mathrm{VI}^{\text {th }}$ International Eurasian Educational Research Congress'de sözlü bildiri olarak sunulmuştur.

${ }^{2}$ Sorumlu Yazar: Eğitim Fakültesi, Temel Eğitim Bölümü, Okul Öncesi Eğitimi Anabilim Dalı, e-posta: ipek.karlidag@ bozok.edu.tr, https://orcid.org/0000-0002-0996-5496

${ }_{3}^{3}$ Eğitim Fakültesi, Eğitim Bilimleri Bölümü, Eğitim Programları ve Öğretim Anabilim Dalı, e-posta: mehmet.saglam@bozok.edu.tr, https://orcid.org/0000-0002-7166-7393
} 
İnsan yaşam süreci içerisinde en önemli ve kritik dönem olan erken çocukluk döneminde (Senemoğlu, 2012); çocuk fiziksel gelişimin yanında duygusal, sosyal, bilişsel ve dil gelişimi açısından da hızlı bir gelişim göstermektedir (Senemoğlu, 2012; Kol, 2011). Gelişimin hızlı olduğu bu dönemde çocuklar dış uyaranlara daha açık, davranış değiştirme ve uyum açısından da daha esnektirler (Barrett, Cooper ve Teoh, 2014). Bu nedenle erken çocukluk döneminde çocuklara verilecek olan eğitimin niteliği çocuğun gelişimi üzerinde önemli çevresel etkenlerden biri olarak karşımıza çıkmaktadır. Okul öncesi eğitim kurumlarının sahip olduğu nitelik düzeyinin çocukların gelişimleri üzerindeki etkilerini inceleyen araştırma bulgularına bakıldığında, nitelik düzeyi yüksek okul öncesi eğitim kurumlarına devam eden çocukların okul başarılarının, bilişsel/dil gelişimlerinin ve sosyal/duygusal yönlerden yeterliklerinin daha yüksek olduğu görülmektedir (Barnett, 1995; Clarke-Stewart, 1992; Peisner-Feinberg ve diğ., 2001; Schweinhart ve Weikard, 1997; Sylva ve diğ., 2007).

Okul öncesi eğitim kurumlarında niteliği etkileyen öğeler ise eğitim programı, fiziksel çevre, sağlık, beslenme ve güvenlik, değerlendirme, yönetim ve çalışan personel (yönetim, öğretmenler ve diğer personel) olarak karşımıza çıkmaktadır. Okul öncesi eğitim kurumlarının niteliğinin çocuk üzerindeki etkileri düşünüldüğünde, okul öncesi eğitim kurumunun niteliğini belirleyen bu değiş̧enlerin mutlaka çocuğun gelişimine uygun olması gerekmektedir (National Association for the Education of Young Children, 2009). İlgili alanyazın incelendiğinde nitelik göstergelerinin yapısal ve işlevsel boyutlar olmak üzere iki boyutta ele alındığı görülmektedir. Niteliğin işlevsel boyutunda, öğretmen çocuk ilişkisi, uyarıcı ve zengin eğitim ortamı ve öğretim etkinlikleri yer alırken niteliğin yapısal boyutunda ise öğretmen başına düşen çocuk sayısı, öğretmenin eğitim durumu, deneyimi, aldığı ücret gibi niteliğin işlevsel boyutunu da etkileyen öğeler yer almaktadır (Organization for Economic Cooperation and Development, 2006; Pianta ve diğ., 2005; Wishard, Shivers, Howes ve Ritchie, 2003). Bu bağlamda okul öncesi eğitim kurumlarında nitelikli bir hizmet sunulmasında öğretmenler belirleyici bir role sahiptir (Dağlığlu, 2012). Öğretmenin sahip olduğu yeterlikler öğrenme sürecinin başarısı üzerinde önemli bir belirleyicidir (Angrist ve Lavy, 2001; Darling-Hammond, 2000; Goe ve Stickler, 2008). Bu doğrultuda öğretmenlik mesleğinin özellikleri göz önünde bulundurularak öğretmenlerin bazı ortak niteliklere sahip olması beklenmektedir.

Öğretmenlerin kişilik özellikleri, öğretmenlik mesleğine yatkınlıkları ve bu mesleği isteyerek seçip seçmedikleri meslekteki başarılarını etkileyen etkenler olarak karşımıza çıkmaktadır (Demirel, 1995). Milli Eğitim Bakanlığı'nca 2002 yılında başlatılan Temel Eğitime Destek Projesi kapsamında yapılan çalışmalar sonucunda bir öğretmenin coşkulu, içten, güvenilir ve yaratıcı bir kişilik yapısına sahip olması; mesleki değerler açısından içinde yaşadığı toplumun kültürel özelliklerini bilmesi, alanındaki gelişmelerden ve bilimsel araştırmalardan yararlanarak kendini sürekli geliştirmesi; sınıfında bulunan öğrencilerin gelişim düzeylerini, öğrenme biçimlerini, güçlü ve zayıf yönlerini, ilgi ve gereksinimlerini doğru biçimde çözümleyip (analiz edip) öğrencilerini tanıyabilmesi; öğretme ve öğrenme sürecini etkin bir şekilde 
planlayarak kalıcı ve anlamlı öğrenmeler sağlaması; her öğrenme sürecinin sonunda etkili değerlendirme yöntemlerini kullanarak öğrencilerin öğrenme ve gelişimini izlemesi ve içinde bulunduğu çevrenin doğal, sosyo-kültürel ve ekonomik özelliklerin farkında olarak okul-aile-toplum ilişkisini sağlaması gerektiği belirtilmektedir (Milli Eğitim Bakanlığı Öğretmen Yetiştirme ve Geliştirme Genel Müdürlüğü, 2017).

Öğretmenlik mesleği genel yeterlikleri çerçevesinde öğretmenin bu yeterliklere sahip olmasında öğretmen yetiştirme sorumluluğunu üstlenen üniversite eğitim fakülteleri önemli bir işleve sahiptir. Eğitim fakülteleri öğretmen eğitiminde özellikle bilimsel birikimin sağlanması, üretilmesi ve öğretmen adaylarına aktarılmasında etkilidirler. Buna karşılık öğretmen eğitiminde gelişmiş ülkeler incelendiğinde kuramsal bilginin aktarılmasının yanı sıra uygulamaya daha çok yer verme eğiliminde oldukları görülmektedir (Doyle, 1986; Garmon, 1993). Bu durumda öğretmenin sahip olması beklenen yeterliklere ulaşmasında öğretmen adayının kuramsal bilgisini uygulama deneyimleri ile bütünleştirmesi gereklidir. Öğretmen adayları ise kuramsal bilgilerini ancak öğretmen olarak göreve başladıklarında tam anlamıyla mesleki deneyimleri ile bütünleştirebilme firsatı bulabilmektedir. Bu nedenle öğretmenlerin mesleki yaşantılarındaki ilk yıllarına ilişkin mesleki deneyimleri önemli bir konu olarak karşımıza çıkmaktadır.

Öğretmenlerin mesleki gelişimleri mesleki yaşantılarının ilk yıllarından itibaren mesleki yaşantı deneyimlerine bağlı olarak oluşmaktadır. Öğretmenler mesleğe başladıkları andan itibaren işyerlerinde deneyimledikleri kişisel ve mesleki olaylar aracılığıyla kişisel bir mesleki gelişim kaydetmektedir (Maskit, 2011). Öğretmenliğin mesleki gelişimi ise farklı araştırmacılar tarafından farklı dönemlere ayrılarak ele alınmaktadır. Ancak genel olarak araştırmacılar öğretmenlik mesleki gelişimini lisans eğitimini kapsayan mesleğe hazırlık süreci ile başlayarak mesleki yaşantının ilk yıllarını kapsayan mesleğe giriş ile birlikte mesleki yaşantının ilerleyen yıllarını kapsayan mesleki süreklilik sonucunda tam bir kariyer gelişimi sağlama süreci olarak değerlendirmektedir (Fuller, 1969; Fuller ve Bown, 1975; Fessler, 1992; akt. Maskit, 2011). Öğretmenlik mesleki gelişim süreci sürekli bir öğrenmenin ürünü olarak okulun tamamında gerçekleşen artan sayıda bilgi ve anlayış, öğretim yeterlikleri edinimi gibi bir dizi deneyimin toplamıdır (Fullan, 2007). Bu bağlamda öğretmenlik mesleki gelişiminin öğretmenlerin kariyerlerinin başlangıcından itibaren karşılaşabilcekleri tüm deneyimleri kapsadığı belirtilebilir.

Öğretmenlik mesleki gelişim süreci öğretmenlerin profesyenel kariyerleri boyunca şekillendirdikleri dirik (dinamik) bir süreçtir. Bu süreçte öğretmenler sınıfta ve çalışma ortamı olarak okuldaki çalışmaları sırasında edindikleri deneyimler sonucunda oluşturdukları ve içselleştirdikleri çeşitli anlayışlar yoluyla bir mesleki gelişim süreci göstermektedir. Öğretmenlik mesleki gelişim sürecinin incelendiği çalışmalarda öğretmenlerin mesleki yaşantıları boyunca farklı mesleki gelişim aşamalarından geçtikleri görülmektedir (Maskit, 2011). Öğretmenlerin her bir gelişim aşamasında ise farklı konular üzerinde bir gelişim çabası içinde oldukları görülmektedir. Öğretmenlik mesleki gelişim sürecinin aşamaları dikkate alındığında 
özellikle lisans eğitimini kapsayan mesleğe hazırlık dönemi (Burke ve diğ., 1987; Vonk, 1991) ile öğretmenlerin mesleğe atanmasıyla başlayan ve mesleki yaşantının ilk yıllarını kapsayan mesleğe giriş dönemi (Huberman, 1989; Vonk, 1991) oldukça önemlidir. Çünkü bu iki dönem içerisinde mesleki olarak edindikleri gözlemler ve deneyimler onların bir profesyonel olarak mesleki bir kimlik oluşturmalarında oldukça etkilidir. Özellikle bu iki dönem içerisindeki deneyimlere bağlı olarak yapılan değerlendirmeler sonucunda kişilerin başka bir alana yönelebildikleri ya da meslekten ayrılma kararı bile alabildikleri görülmektedir (Heick, 2018). Bu açıdan bakıldığında bu dönemlerde yaşanacak deneyimlerin öğretmenlerin mesleki gelişimini farklı şekillerde etkileyebileceği açıktır.

Lisans eğitimini kapsayan yıllarda oluşan mesleğe hazırlık dönemi bireylerin profesyonel bir kimlik oluşturma sürecine hazırlanmalarını kapsayan ve mesleğin gereğini karşılamak için gereksinim duydukları bilgi, beceri ve tutumları kazandıkları (Vonk, 1991) bu dönem bireylerin öğretmenlik mesleğine neden ilgi duydukları ve bu mesleğin kendilerine uygun olup olmadığına ilişkin çeşitli yorumlar yaptıkları bir dönemdir (Aydın, 2018). Mesleki yaşantının ilk yıllarını kapsayan mesleğe giriş dönemi ise bireylerin mesleğe atanması ile başlayan ve ilk bir ila üç yılı kapsamaktadır (Huberman, 1989). Bu dönem içerisinde öğretmenler öğrenciler, meslektaşları ve yöneticileri tarafından kabul görmek için çeşitli durumlar karşında çabalarken güvenli ve rahat bir düzen oluşturmaya çalışırlar (Maskit, 2011).

Öğretmenlik mesleki gelişimi açısından ilk y1l deneyimleri üzerine yapılan çalışmalar incelendiğinde mesleğin ilk yıllarında öğretmenlerin çeşitli zorluklarla karş1 karşıya kaldıkları görülmektedir. Yürütülen çalışmalarda öğretmenlerin genellikle öğrencilerin farklı gelişimsel gereksinimlerini anlama, günlük sınıf ve okul yaşamı işlerini yönetme, yaratıcı öğretim programları tasarlama, mesleki gelişim açısından kendilerini geliştirme firsatları yakalama, yönetici, öğretmen, ebeveynlerle ve meslektaşlarıyla olumlu etkileşimler oluşturma ve toplum tarafindan gerekli değeri görme, materyal ve kaynakların yetersiz olması, farklı kültürden gelen öğrencilerle ilgilenememe gibi konularda sıkıntılar yaşadıkları belirtilmektedir (Fuller, 1969; Güçlü, 2004; Johnston, 2002; Kane, 1991; Michie, 1999; Roehrig, Pressley ve Talotta, 2002; Sünbül, 2005; Veenman, 1984; Yalçınkaya, 2002). Bu sorunların yanında öğretim sürecine hazırlanmada yetersiz kalma, öğrenme sürecini etkili planlayamama ve yeterli desteğe sahip olamama sorunları da bulunmaktadır (Bolich, 2001; Brock ve Grady, 2005). Veenman'nin (1984) tarama çalışmasında ise yeni öğretmenlerin sınıf yönetimi, öğrenciyi güdüleme, bireysel farklılıklara uygun öğrenme süreçleri planlayabilme, öğrencileri değerlendirme ve ailelerle iletişim kurabilme noktalarında büyük zorluklar yaşadıklarını belirtilmektedir. Genel olarak mesleğe yeni başlayan öğretmenlerin yaşadığı bu sorunların, öğretmenlik mesleğine ve bir işyeri olarak okul ortamının koşullarına bağlı olarak gelişmekte olduğu görülmektedir (Glickman, Gordon ve Ross-Gordon, 2004).

Pekçok araştırma sonucunda bu zorluklar karşısında öğretmenlerin genellikle çağdaş öğretim yaklaşımlarını kullanmayı terk ettikleri ve güdülenme düzeylerinde 
de azalma olduğu ortaya konulmuştur (Flores, 2006; Schempp, Sparkes ve Templin, 1998). Bunun yanında hiçbir profesyonel desteğin olmadığı zor bir başlangıç sürecinde öğretmenlerin ciddi bir şekilde yıprandıkları da belirtilmektedir (Hong, 2010; Torres, 2012). Buna bağl1 olarak çoğu araştırma öğretmenlerin ilk yıl deneyimlerine odaklanmaktadır (Farrell, 2003; Sabar, 2004).

İlgili alanyazın incelendiğinde araştırmaların genellikle diğer branşlarda görev yapan öğretmenlerin yaşadıkları sorunlara yönelik olduğu görülmektedir (Afşin, 1988; Erdemir, 2007; Ergenekon, 2004; Erkoç, 2010; Hamarat, 2002; Korkmaz, 1999; Korkmaz, Saban ve Akbaşl1, 2004; Kösterelioğlu ve Kösterelioğlu, 2008; Öztürk, 2016; Sarı ve Altun, 2015). Okul öncesi öğretmenlerinin yaşadıkları sorunların belirlenmesi ile ilgili yalnız birkaç araştırmaya rastlanırken (Aktankerem ve Cömert, 2006; Bağçeli-Karaman, Şen, Alataş ve Tütüncü, 2018; Başturan, 2018; Başaran, Gökmen ve Akdağ, 2014; Demircan-Aydın, 2017; Erden, 2010; Kaplan, 2015; Kök, Küçükoğlu, Tuğluk ve Koçyiğit, 2007; Zembat, 2012), okul öncesi öğretmenlerinin ilk yıllardaki mesleki deneyimlerine yönelik bir çalışmaya rastlanamamıştır. $\mathrm{Bu}$ nedenle bu araştırmanın amacı, okul öncesi öğretmenlerinin meslek yaşantılarının ilk yıllarına ilişkin deneyimlerinin neler olduğunu ortaya çıkarmaktır. Bu genel amaç çerçevesinde okul öncesi öğretmenlerine ilişkin aşağıdaki sorulara yanıt aranmıştır:

1. Lisans yıllarının sonlarında mesleğe ilişkin beklentileri nelerdi?

2. Mesleğe başladıkları ilk yılın başlarında hissettikleri duygular nelerdi?

3. Meslek yaşantılarının ilk yıllarında yaşadıkları sorunlar nelerdir?

4. Meslek yaşantılarının ilk yıllarında yaşadıkları sorunların üstesinden gelme yöntemleri nelerdir?

5. Meslek yaşantılarının ilk yıllarında yaşadıkları sorunlardaki değişim nasııldı?

6.Meslek yaşantılarının ilk yıllarında edindikleri öğretmenlik meslek deneyimlerinin mesleki gelişimlerine katkısı ne olmuştur?

\section{Yöntem}

Bu bölümde araştırma modeli, çalışma grubu, veri toplama araçları, veri toplama süreci, verilerin analizi ile araştırmanın geçerliği ve güvenirliği hakkında bilgilere yer verilecektir. Araştırma 01.01.2020 tarihinden önce yapıldığı için etik kurul kararı zorunluluğu taşımamaktadır.

\section{Araştırma Modeli}

$\mathrm{Bu}$ araştırma nitel bir çalışma olup araştırmanın yöntemini sözlü tarih yöntemi oluşturmaktadır. Sözlü tarih; bireylerin, toplumun farklı kesimlerinin yaşam biçimlerini, onların tarihsel çalışmalardaki toplumsallaşma öğelerini önemseyen ve toplumsal tarihe katkı sağlayan disiplinler arası bir tarihsel yaklaşımdır (İlyasoğlu, 2006; Thompson, 2017). Bu yöntem temelde egemen tarih yazımı dışında tutulan 
kesimlerin yaşamlarına ilişkin ayrıntıları ortaya çıkarmada ve onları tarih yazımının bir parçası durumuna getirmede önemli bir işleve sahiptir (Tan, 2000).

Eğitimin bileşenleri olan öğrenciler, öğretmenler ve veliler gibi kesimlerin gerek eğitim deneyimlerine gerekse mesleki deneyimlerine yazılı belgelerde ulaşmak neredeyse olanaksızdır. Bu deneyimleri ortaya çıkarmada sözlü tarih önemli bir araç olarak karşımıza çıkmaktadır. Bu kesimlerin eğitime özgü çalışmalarda onların belleklerinde anıya dönüşmüş eğitim deneyimlerine başvurmak araştırmacılara kayda değer veri sunmaktadır (McAdoo, 1980; Sağlam, 2015). Ayrıca sözlü tarih görüşmeleri günlük ezberden anlatılan anılar değil, yapılandırılmış ve amaçlı oturumlardır. Görüşme tekniğinden farklı olarak sözlü tarih görüşmelerinde katılımcının belirli bir zamanda, yeri ve olayı tasvirinden birinci elden bilgiler elde edilmektedir (MacKay, Quinlan ve Sommer, 2013; akt. Dere ve Dinç, 2020). Bu bağlamda bu araştırmada da sözlü tarih yöntemi okul öncesi öğretmenlerinin meslek yaşantılarının ilk yıllarına ilişkin anlatılarını ortaya çıkarmada etkili bir araç olduğu için tercih edilmiştir.

\section{Çalışma Grubu}

Çalışma grubu olasılıklı olmayan örnekleme türlerinden amaçlı örnekleme yöntemlerinden kolay ulaşılabilir durum örneklemesi yoluyla oluşturulmuştur. $\mathrm{Bu}$ yöntem çalışmanın amacına bağlı olarak bilgi açısında zengin durumların seçilerek derinlemesine araştırma yapılmasına olanak tanırken (Bernard, 2011) yakın ve erişilmesi kolay olan bir durum seçildiği için araştırmaya hız kazandıran bir yöntemdir (Creswell, 2013). Çalışma grubunda yer alan katılımcıların \%10'u erkek $(n=2)$, \%90'nı ise kadın ( $\mathrm{n}=18$ ) okul öncesi öğretmenidir. Katılımcıların hepsi lisans mezunu iken, yaşları 27-48 yaş arasında ve mesleki deneyim süreleri ise 4-20 yıl arasında değişmektedir (Tablo 1).

Tablo 1

Çalışma Grubuna İlişkin Demografik Bilgiler

\begin{tabular}{llccc}
$\begin{array}{l}\text { Katılımcı } \\
\text { Kodu }\end{array}$ & Cinsiyet & Yaş & Eğitim Düzeyi & $\begin{array}{c}\text { Mesleki } \\
\text { Deneyim } \\
\text { Süresi }\end{array}$ \\
\hline Ö1 & Kadın & 28 & Lisans & 6 \\
\hline Ö2 & Kadın & 32 & Lisans & 8 \\
\hline Ö3 & Kadın & 48 & Lisans & 17 \\
\hline Ö4 & Erkek & 42 & Lisans & 20 \\
\hline Ö5 & Erkek & 35 & Lisans & 10 \\
\hline Ö6 & Kadın & 33 & Lisans & 10 \\
\hline Ö7 & Kadın & 29 & Lisans & 4 \\
\hline Ö8 & Kadın & 31 & Lisans & 6 \\
\hline Ö9 & Kadın & 38 & Lisans & 14 \\
\hline Ö10 & Kadın & 31 & Lisans & 8 \\
\hline & & & & (devam ediyor)
\end{tabular}


Tablo 1 (devam)

\begin{tabular}{ccccc}
\hline $\begin{array}{c}\text { Katılımeı } \\
\text { Kodu }\end{array}$ & Cinsiyet & Yaş & Eğitim Düzeyi & $\begin{array}{c}\text { Mesleki } \\
\text { Deneyim } \\
\text { Süresi }\end{array}$ \\
\hline Ö11 & Kadın & 39 & Lisans & 15 \\
\hline Ö12 & Kadın & 27 & Lisans & 5 \\
\hline Ö13 & Kadın & 34 & Lisans & 13 \\
\hline Ö14 & Kadın & 35 & Lisans & 14 \\
\hline Ö15 & Kadın & 38 & Lisans & 17 \\
\hline Ö16 & Kadın & 40 & Lisans & 10 \\
\hline Ö17 & Kadın & 38 & Lisans & 10 \\
\hline Ö18 & Kadın & 39 & Lisans & 12 \\
\hline Ö19 & Kadın & 30 & Lisans & 7 \\
\hline Ö20 & Kadın & 35 & Lisans & 11 \\
\hline
\end{tabular}

\section{Veri Toplama Araçları}

Sözlü tarih yönteminde veri toplama aracı olarak çoğunlukla görüşme tekniği tercih edilmektedir (Arat, 2003). Bu araştırmanın verileri de okul öncesi öğretmenleri ile yapılan görüş̧meler yoluyla elde edilmiştir. $\mathrm{Bu}$ görüşmeler araştırmacılar tarafından geliştirilen yarı yapılandırılmış soruların öğretmenlere yöneltilmesiyle gerçekleştirilmiştir. Yarı yapılandırılmış görüşme formu iki bölümden oluşmaktadır. Birinci bölümde katılımcılara ilişkin cinsiyet, yaş, eğitim düzeyi ve mesleki deneyim süresi olmak üzere demografik bilgiler yer alırken, ikinci bölümde ise okul öncesi öğretmenlerinin meslek yaşantılarının ilk yıllardaki (1-3 yıl) deneyimlerini ortaya çıarmaya yönelik tasarlanmış altı açık uçlu soru bulunmaktadır.

\section{Veri Toplama Süreci}

$\mathrm{Bu}$ araştırmada öncelikle öğretmenlerin görüşme için uygun oldukları zaman bilgisi alınarak bir görüşme takvimi oluşturulmuştur. Görüşme takviminin oluşturulmasındaki amaç katılımcının uygun ve rahat olduğu zaman diliminde görüşmelerin yapılması sağlanarak görüsşmelerin etkili ve verimli olabilmesidir. Görüsşmelerin hepsi öğretmenlerin çalıştığ kurumda yer alan uygun bir çalışma odasında gerçekleştirilmiştir. Görüşme gerçekleştirilmeden önce her katılımcı araştırma konusu ve amaçları ile hakları konusunda bilgilendirilmiştir. $\mathrm{Bu}$ bilgilendirmenin ardından katılımcılardan bu görüşmeye gönüllü olarak katıldıklarına ilişkin onayları alınmıştır. Ardından her katılımeı doğduğu yer, yıl, eğitim durumu ve mesleğini gösteren sözlü tarih veri belgesi doldurmuştur. Görüşmenin başında katılımcılar demografik durumları ile ilgili sorulara yanıt verdikten sonra görüşme yarı yapılandırılmış görüşme soruları üzerinden yürütülmüştür. Görüşmeler tamamlandıktan sonra her bir görüşme için görüşme sürecinin nasıl gerçekleştiğini anlatan sözlü tarih hikayesi yazılmışıtır. Veri toplama süreci 17 Aralık 2018 ile 10 Ocak 2019 tarihleri arasında tamamlanmıştır. 


\section{Verilerin Analizi}

$\mathrm{Bu}$ araştırmada elde edilen verilerin analizinde içerik analiz yöntemi kullanılmıştır. İçerik analizinde elde edilen verileri açılayan kavramların ve ilişkilerin ortaya konulması söz konusudur. Diğer bir deyişle içerik analizinde birbirine benzeyen veriler belli kavramlar ve temalar çerçevesinde bir araya getirilerek düzenlenir ve yorumlanır (Weber, 1990). Bunun için öncelikle katılımcılarla yapılan görüşmelerde alınan ses kayıtları metne dönüştürülmüştür. Görüşme metinleri araştırmacıların görüş birliğine dayalı olarak analiz edilmesine dikkat edilerek değerlendirilmiş, böylece geçerlik ve güvenirlik sağlanmaya çalışılmıştır (Creswell ve Miller, 2000). Bu doğrultuda içerik analizinin geçerlik ve güvenirliğini sağlayabilmek için bağımsız kodlama süreci uygulanmıştır. Bağımsız kodlama sürecinde araştırmacılar öncelikle bireysel olarak görüş̧me metinlerini incelemiş ve kendi kodlarını oluşturmuştur. Ardından her iki araştırmacı bir araya gelerek ortaya çıkardıkları tema ve kodları karşılaştırmış, sorgulamış ve ilgili alanyazından yararlanarak kodları sadeleştirmiştir. Bu süreç tüm tema ve kodlar üzerinde görüş birliğine varana kadar devam etmiştir. Son olarak altı kategori altında temalar düzenlenmiştir.

\section{Araștırmanın Geçerlik ve Güvenirliği}

$\mathrm{Bu}$ araştırma nitel bir araştırma olup elde edilen veriler görüşmeler aracıllğıyla toplanmıştır. Nitel bir araştırmada elde edilen verilerin ayrıntılı biçimde raporlanması ve elde edilen bulgulara nasıl ulaşıldığının açıklanması geçerlik ve güvenirlik için önemli ölçütleridir (Yıldırım ve Şimşek, 2016). Nitel araştırma sürecinde iç geçerliğe ilişkin araştırma bulgularının anlamlı ve kendi içinde tutarl, alanyazın ile uyumlu ve ortaya çıkan kavramların anlamlı bir bütün oluşturması gerekmektedir (Miles ve Huberman, 2015). Bu bağlamda bu araştırmada öncelikli olarak yarı yapılandırılmış görüşme formu hazırlanırken araştırma soruları temel alınarak ilgili alanyazından yararlanılmıştır. Görüşme formunda yer alan soruların açık ve anlaşılır ifadelerden oluşmasına dikkat edilmiştir. Görüşme formu oluşturulduktan sonra iki uzmanın görüşlerine başvurularak soruların kullanılacağı amaca ve örnekleme uygunluğuna ilişkin görüşler alınmıştır. $\mathrm{Bu}$ görüşler doğrultusunda düzenlemeler yapılarak oluşturulan görüşme formunun iki okul öncesi öğretmeni ile yapılan pilot görüşmeler yoluyla ön denemesi yapılmıştır. Pilot görüşmelerden alınan dönütler doğrultusunda görüşme formuna son biçimi verilerek araştırmanın verileri toplanmaya başlanmıştır. Veri toplama sürecinde görüşme formunda yer alan sorular konuşma tarzında sorulmuş ve katılımcıların kendilerini rahat ifade edebilecekleri bir ortam oluşturulmaya çalışılmıştır. Bunların yanında iç geçerlik katılımcı teyidi ve bulguların doğrudan alıntılarla desteklenmesi ile sağlanmaya çalışılmıştır. Araştırmanın güvenirliği ise tüm araştırma sürecinin ayrıntılı olarak betimlenmesiyle gerçekleştirilmeye çalışılmıştır. Bireysel varsayımlar ve önyargılar araştırmaya yansitılmamış, görüşmelerde ses kayıt cihazı ile toplanan ham veriler başkaları tarafindan incelemeye uygun bir şekilde saklanmıştır.

\section{Bulgular}

Araştırmanın bu bölümünde öğretmenlerle yapılan görüşmelerden elde edilen veriler araştırmanın alt problemleri temel alınarak sunulmuştur. 


\section{Birinci Alt Probleme İlişkin Araștırma Bulguları}

Okul öncesi öğretmenlerinin lisans öğrenimlerinin son yılında geleceğe yönelik beklentileri Tablo 2'de sunulmuştur.

Tablo 2

Okul Öncesi Öğretmenlerinin Lisans Öğrenimlerinin Son Yllında Geleceğe Yönelik Beklentileri

\begin{tabular}{llr}
\hline Tema & Kodlar & f \\
\hline & Mesleğe atanmak & 8 \\
& Yararcı bir öğretmen olmak & 6 \\
& Sabırlı bir öğretmen olmak & 5 \\
Geleceğe & Risk almaya istekli bir öğretmen olmak & 5 \\
Yönelik & Coşkulu bir öğretmen olmak & 4 \\
Beklentileri & Yüksek lisans yapmak & 3 \\
& Okul öncesi eğitim ile ilgili olumsuz tutumlarını değiştirmek için & 2 \\
& istekli olmak & \\
\hline
\end{tabular}

Okul öncesi öğretmenlerinin lisans öğrenimlerinin son yılında geleceğe yönelik beklentileri Tablo 2'den incelendiğinde öğretmenlerin en fazla Milli Eğitim Bakanlığı'nda devlet okuluna kadrolu öğretmen olarak mesleğe atanabilmeyi $(n=8)$ ve çocukların gelişimine uygun nitelikli bir eğitim sunabilmeyi arzulayan yararcı bir öğretmen olabilmeyi $(n=6)$ istedikleri görülmektedir. Bunun yanında sabırlı $(n=5)$ ve coşkulu ( $n=4)$ bir öğretmen olabilmenin mesleğe başlamadan önce geleceğe yönelik hedefleri arasında olduğu görülmektedir. Ayrıca öğretmenlerin yüksek lisans yaparak kendilerini geliştirmek istedikleri $(n=3)$ ve ayrıca toplumun okul öncesi eğitim ile ilgili olumsuz tutumlarını değiştirmek için istekli olduklarını $(n=2)$ dile getirdikleri görülmektedir. Bu beklentileri dikkate alındığında öğretmenlerin mesleğe başlamadan önce risk almaya istekli öğretmenler olmak istedikleri $(n=5)$ görülmektedir.

Okul öncesi öğretmenlerinin lisans öğrenimlerinin son yılında geleceğe yönelik beklentilerine ilişkin örnek ifadeler şu şekildedir:

Üniversite son sınıfta, tabi ki son sınıf öğrencisisin, işte o zaman KPSS gibi bir derdin var. Bir an önce KPSS'de yüksek bir puan alıp atanma hayalindeydik. Zaten çok beklemedim üniversite bitti hemen yedi ay sonra atandım. (Ö2 kodlu öğretmen)

Çocukların hayatına dokunmak istiyordum çünkü ilk yıllarda alınan eğitimin çok önemli olduğunu düşünüyorum. O yüzden çocukları başta ben eğiteceğim için çok heyecanlıydım. 0-6 yaş arası çocukların ileriki yaşlarındaki gelişimini \% 70 etkilediği için daha güzel etkinlikler, daha güzel bir eğitim vermeye çalışmayı istiyordum. (Ö12 kodlu öğretmen) 


\section{İkinci Alt Probleme İlişkin Araştırma Bulguları}

Tablo 3 'te okul öncesi öğretmenlerinin mesleğe başladıkları ilk yılın başlarında hissettikleri duygular verilmiştir.

Tablo 3

Okul Öncesi Öğretmenlerinin Illk Yllki Mesleki Yaşantlarının Başlarinda Hissettikleri Duygular

\begin{tabular}{llc}
\hline Tema & Kodlar & f \\
\hline \multirow{4}{*}{ Duygular } & Mutluluk & 10 \\
& Heyecan & 5 \\
& Tedirginlik & 5 \\
& Hayal kırıklığı & 4 \\
& Korku & 4 \\
& Belirtmeyen & 2 \\
& Stres & 1 \\
\hline
\end{tabular}

Tablo 3'te yer alan okul öncesi öğretmenlerinin mesleğe başladıkları ilk yılın başlarında hissettikleri duygular incelendiğinde en fazla mutluluk $(\mathrm{n}=10)$, heyecan $(\mathrm{n}=5)$ ve tedirginlik $(\mathrm{n}=5)$ duygularını yaşadıkları görülmektedir. Bunun yanında hayal kırıklığ $1(n=4)$, korku $(n=4)$, stres $(n=1)$ ve umutsuzluk $(n=1)$ duygularını yaşadığını ifade eden öğretmenler de bulunmaktadır.

Okul öncesi öğretmenlerinin mesleğe başladıkları ilk yılın başlarında hissettikleri duygulara ilişkin örnek ifadeler şu şekildedir:

Ben aslında öğretmenlik mesleğini çok isteyerek tercih etmemiştim. Bu yüzden endişelerim vardı, sabırlı davranabilir miyim açısından çok endişeliydim. Sadece bu açıdan bir endişem vardı. Tabi ki çocukları sevdiğim için de bu mesleği yapacağım için sevinçliydim ve atandığım için çok mutlu olmuştum. (Ö7 kodlu öğretmen)

Çalışmaya ilk başladığımda çok endişeliydim. Tecrübesiz olduğum için doğal olarak. Daha doğrusu sonrasında ben idarecilik yaptım bir dönem, sekiz yıl kadar. İdarecilikten sonra tekrar öğretmenliğe dönüş yaptım. Bu süre zarfinda hem deneyimim hem de tecrübem arttı. Gözlem yeteneğim gelişti. Daha olumlu düşünmeyi öğrendim. Eğitimsel olarak daha olumlu bir bakış açısı geliştirdim. Çünkü biz her yıl yenileniyoruz, öğrencilerimiz değişiyor, ortam ve şartlar her şey yenileniyor. (Ö13 kodlu öğretmen)

\section{Üçüncü Alt Probleme İlişkin Araştırma Bulguları}

Okul öncesi öğretmenlerinin meslek yaşantılarının ilk yıllarında yaşadıkları sorunlar incelendiğinde yaşadıkları sorunların çok çeşitli olduğu görülmektedir. $\mathrm{Bu}$ sorunlar; eğitim ortamı ve öğretmenlik meslek becerileri ile ilgili sorunlar, meslektaşları, okul yönetimi, çocuklar, veliler ve toplum ile yaşadıkları sorunlar ve 
diğer sorunlar alt temaları altında değerlendirilmiştir. Okul öncesi öğretmenlerinin meslek yaşantılarının ilk yıllarında yaşadıkları sorunlar Tablo 4 'te verilmiştir.

Tablo 4

Okul Öncesi Öğretmenlerinin Meslek Yaşantılarının İlk Yıllarında Yaşadıkları Sorunlar

\begin{tabular}{|c|c|c|c|}
\hline Tema & Alt Tema & Kodlar & $\mathbf{f}$ \\
\hline \multirow{24}{*}{ 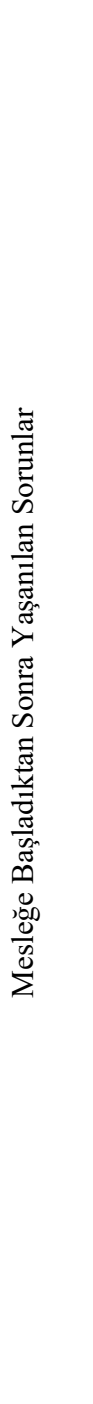 } & \multirow{9}{*}{$\begin{array}{l}\text { Eğitim Ortamı ile } \\
\text { İlgili Yaşadıkları } \\
\text { Sorunlar }\end{array}$} & Mobilya ve materyal yetersizliği & 10 \\
\hline & & $\begin{array}{l}\text { Okul binasının fiziksel koşullarının uygun } \\
\text { olmaması }\end{array}$ & 7 \\
\hline & & Sinıfin sobalı olması & 5 \\
\hline & & $\begin{array}{l}\text { Atandığı yerde düzenlenmiş bir okul öncesi eğitim } \\
\text { sinıfinın olmaması }\end{array}$ & 3 \\
\hline & & $\begin{array}{l}\text { Çocuk sayısına göre metrekaresi küçük bir sınıfa } \\
\text { sahip olunması }\end{array}$ & 2 \\
\hline & & Temiz ve hijyenik bir ortamın olmaması & 2 \\
\hline & & Sinıflarda yardımcı personelin olmaması & 2 \\
\hline & & $\begin{array}{l}\text { Öğretmenlerin dinlenebilmesi için yeterli } \\
\text { zamanının olmaması }\end{array}$ & 1 \\
\hline & & $\begin{array}{l}\text { Öğretmen olarak atandıkları yerin kültürüne uyum } \\
\text { sağlama sürecinin zor olması }\end{array}$ & 1 \\
\hline & \multirow{6}{*}{$\begin{array}{l}\text { Öğretmenlik } \\
\text { Meslek Becerileri } \\
\text { ile İlgili } \\
\text { Yaşadıkları } \\
\text { Sorunlar }\end{array}$} & Sınıf yönetiminde zorluklar yaşama & 6 \\
\hline & & Ebeveynlerle etkili iletişim kuramama & 3 \\
\hline & & Çocuklarla etkili iletişim kuramama & 2 \\
\hline & & Öğretmenlik mesleğine ilişkin deneyim eksikliği & 2 \\
\hline & & $\begin{array}{l}\text { Kaynaştırma ve özel eğitim konusunda yetersiz } \\
\text { olma }\end{array}$ & 2 \\
\hline & & $\begin{array}{l}\text { Eğitim yılı başında okula uyum sürecinde yaşanan } \\
\text { problemlerle baş etmede yaşanan güçlükler }\end{array}$ & 2 \\
\hline & Meslektaşları ile & Deneyimli öğretmenlerden yeterli destek alamama & 2 \\
\hline & $\begin{array}{l}\text { İlgili Yaşadıkları } \\
\text { Sorunlar }\end{array}$ & $\begin{array}{l}\text { Kişisel çekişmelerin ve buna bağlı bir rekabet } \\
\text { ortamının olması }\end{array}$ & 1 \\
\hline & \multirow{2}{*}{$\begin{array}{l}\text { Okul Yönetimi ile } \\
\text { İlgili Yaşadıkları } \\
\text { Sorunlar }\end{array}$} & $\begin{array}{l}\text { İlköğretim yönetiminin anasınıflarını önemli } \\
\text { görmemesi }\end{array}$ & 1 \\
\hline & & $\begin{array}{l}\text { Okul yönetimi ile öğretmenler arasında iş birliğine } \\
\text { dayalı çalışmanın yetersizliği }\end{array}$ & 1 \\
\hline & $\begin{array}{l}\text { Çocuklar ile İlgili } \\
\text { Yaşadıkları } \\
\text { Sorunlar }\end{array}$ & Anadillerinin farklı olması & 7 \\
\hline & $\begin{array}{l}\text { Veliler ile İlgili } \\
\text { Yaşadıkları }\end{array}$ & $\begin{array}{l}\text { Okul öncesi eğitime yönelik farkındalığın yetersiz } \\
\text { düzeyde olması }\end{array}$ & 7 \\
\hline & Sorunlar & Eğitim sürecine katılımlarının yetersiz olması & 3 \\
\hline & Toplum ile İlgili & $\begin{array}{l}\text { Genel anlamda okul öncesi öğretmenlerine "bakıcı" } \\
\text { gözüyle bakı1lıyor olması }\end{array}$ & 4 \\
\hline & Sorunlar & $\begin{array}{l}\text { "Erkek okul öncesi öğretmeni olmaz" düşüncesinin } \\
\text { hakim olması }\end{array}$ & 2 \\
\hline
\end{tabular}


Tablo 4 (devam)

\begin{tabular}{lllc}
\hline Tema & Alt Tema & Kodlar & f \\
\hline Mesleğe & & Hazırlayıcı temel eğitiminin eğitim öğretim & 1 \\
Başladıktan & Diğer & sürecinde verilmesi & \\
Sonra & Yaşadıkları & Hazırlayıcı temel eğitimin belli yerlerde verilmesine & 1 \\
$\begin{array}{l}\text { Yaşanılan } \\
\text { Sorunlar }\end{array}$ & Sorunlar & bağlı ulaşım problemlerinin yaşanması & \\
\hline
\end{tabular}

Tablo 4'ten öğretmenlerin eğitim ortamı ile ilgili belirttikleri sorunlar arasında mobilya ve materyal eksiklerinin olması $(\mathrm{n}=10)$, okul binasının fiziksel koşullarının uygun olmaması $(n=7)$, sınıfın ısınmasının soba ile sağlanıyor olması $(n=5)$, atandıkları yerde düzenlenmiş bir okul öncesi eğitim sınıfının olmaması $(n=3)$, çocuk sayısına göre metrekaresi küçük bir sınıfın olması $(n=2)$, temiz/hijyenik bir ortamın olmaması $(\mathrm{n}=2)$, sinıflarda yardımc1 personelin olmaması $(\mathrm{n}=2)$, öğretmenin dinlenebilmesi için yeterli zamanının olmaması $(\mathrm{n}=1)$ ve öğretmen olarak atandıkları yerin kültürüne uyum sağlama sürecinin zor olması $(n=1)$ durumlarının olduğu anlaşılmıştır. Öğretmenlerin öğretmenlik meslek becerileri ile ilgili yaşadıkları sorunların sınıf yönetimi $(n=6)$, ebeveynlerle etkili iletişim kurma $(n=3)$, çocuklarla etkili iletişim kurma $(\mathrm{n}=2)$, öğretmenlik mesleğine ilişkin deneyim eksikliği $(\mathrm{n}=2)$, özel eğitim ve kaynaştırma $(n=2)$ ile uyum süreci $(n=2)$ konularında olduğu görülmüştür.

Öğretmenlerin meslektaşları ile ilgili sorun yaşadıklarına yönelik az sayıda anlatıyla karşılaşılmıştır. Bu anlatılarda yaşanılan sorunlar incelendiğinde, deneyimli öğretmenlerden yeterli destek alamama $(\mathrm{n}=2)$ ve öğretmenler arası kişisel çekişmelere bağlı öğretmenler üzerinde olumsuz etkisi olan bir rekabet ortamının olması $(\mathrm{n}=1)$ gibi ifadeler öne çıkmıştır. Okul yönetimi/yönetimsel sorunlar konusunda da benzer bir durum görülmektedir. $\mathrm{Bu}$ anlatılar ilköğretimde açılmış olan anasınıflarının yönetim tarafindan önemli görülmemesi $(\mathrm{n}=1)$ ve okul yönetimi ile öğretmenler arasında işbirliğine dayalı çalışmanın yetersiz olmasını $(\mathrm{n}=1)$ içermektedir.

Anlatılarda ortaya çıkan tüm bu sorunların yanında çocukların anadillerinin farklı olması $(\mathrm{n}=7)$ çocuklar ilgili yaşanan tek sorun olarak anlatılarda yer almıştır. Öğretmenlerin veliler ile ilgili yaşadıkları sorunların ise ebeveynlerin okul öncesi eğitime yönelik farkındalığının yetersiz düzeyde olması $(n=7)$ ve ebeveynlerin eğitim sürecine katılımlarının yetersiz olması $(n=3)$ nedeniyle olduğu anlaşılmıştır. Genel anlamda okul öncesi öğretmenlerine "bakıcı" gözüyle bakılıyor olması $(n=4)$ ve "Erkek okul öncesi öğretmeni olmaz" düşüncesinin hakim olması $(n=2)$ şeklinde anlatılarda ifade edilen sorunlar ise öğretmenlerin toplum ile ilgili yaşadıkları sorunlar arasında yer almaktadır. Son olarak Milli Eğitim Bakanlığınca yeni atanan öğretmenlere verilen hazırlayıcı temel eğitimin eğitim öğretim sürecinden önce verilmemesi $(n=1)$ ve Milli Eğitim Bakanlığınca yeni atanan öğretmenlere verilen hazırlayıcı temel eğitimin belli yerlerde verilmesine bağlı ulaşım problemlerinin yaşanması $(n=1)$ öğretmenler tarafından ifade edilen diğer sorunlar olarak belirlenmiştir. 
Okul öncesi öğretmenlerinin mesleğe ilk başladıklarında yaşadıkları sorunlardan "eğitim ortamı ile ilgili sorunlar" alt temasına yönelik örnek ifadeler şu şekildedir:

Atandıktan sonra atandığım yere gittim. Çevreyi tanıdım. Tabi zor şartlarım vardı. Okulum samanlıktan bozma bir okuldu. Öğrencilerin şiveleri, konuşmaları çok farklıydı. Zaman geçtikçe onların şiveleriyle konuşmaya başlar olduğumu hatırlıyorum mesela. Malzemem yoktu. Fiziksel ortam çok kötüydü. Çok dar bir ortamdı. Masalar, sandalyeler sınıfa sığmıyordu. Sınıfta soba yakmak zorundaydık. Temizlik konusunda sıkıntılar söz konusuydu. Mesela okulun temizliğini de bizim yapmamız gerekiyordu. Zor şartlar altında çalıştığımı hatırlıyorum. (Ö14 kodlu öğretmen)

Atandığım anaokulunun binası tarihi bir binaydı yani tarihi bir binayı okul öncesi kurumuna dönüştürmüşlerdi. $\mathrm{Bu}$ nedenle fiziksel özellikler açısından okul öncesi eğitim kurumuna uygun değildi. ...İlk olarak 4 yaş grubu ile çalışmaya başlamışıı. Çok hareketli bir sınıfım vardı. Yani onları sakinleştirmek zordu. Küçük bir sınıftaydık, hareket etme olanaklarımız çok fazla yoktu. Sınıfın dışında arada bir oyun salonu vardı çocukların orada enerji atmalarını sağlamaya çalışıyordum. Öğretmenlerle ve idare ile dediğim gibi hiç sıkıntı yaşamadım. Okulun fiziksel koşulları uygun değildi sadece ama imkanlar açısından mesela materyal bulma, veliyle materyal ihtiyacı hakkında iletişim kurma konularında rahattık. Sınıfın fiziksel imkanları kısitlıydı.

Okul öncesi öğretmenlerinin mesleğe ilk başladıklarında yaşadıkları sorunlardan "öğretmenlik meslek becerileri ile ilgili sorunlar” alt temasına yönelik örnek ifadeler şu şekildedir:

Çocukları aldığımda ilk başta ne yapacağımı bilememe durumu yaşamıştım. Korkularım özellikle sınıf yönetimi konusundaydı. Bu durum ise zaman içerisinde çocukları tanıyarak oturdu. Söylediklerimi yapar hale gelmişlerdi. (Ö16 kodlu öğretmen)

Kaynaştırma öğrencilerinin öğrenme sürecine dahilinde sıkıntılar yaşadım. Tecrübe eksikliği ile ilgili sorunlar daha ön plana çıkıyor. Mesela çocukların dikkati dağıldığı zaman onları nasıl toplayacağımı bilemiyordum. İlk yıl çok yıpratıcı oluyor gerçekten. Çocuğa yaklaşımlar çok acemice oluyor. Belki değiştiremeyeceğin şeyin üstüne çok gidiyorsun ya da değiştirebileceğin şeyleri görememiş olabiliyorsun. (Ö20 kodlu öğretmen)

Okul öncesi öğretmenlerinin mesleğe ilk başladıklarında yaşadıkları sorunlardan "meslektaşları ile ilgili yaşadıkları sorunlar" alt temasına yönelik örnek ifadeler şu şekildedir: 
Meslektaşlarınla da uyum süreci ister istemez yaşıyorsun. Üniversiteden çıkmış bir öğrenci gelip de deneyimli, tecrübeli öğretmenlerin içine girince; yani dünyaya bakış açınız o zaman daha farklı, daha böyle idealistsiniz, istekleriniz daha fazla. Daha hayat dolu ve pek çok şey yapmak istiyorsunuz. Ama onları da meslektaşlarınız biraz nasıl desem böyle çok da gerçekçi bulmuyorlar ve çok desteklemiyorlardı. (Ö9 kodlu öğretmen)

Sadece şey ögretmenler arasında geldiğimde bir gruplaşma vardı. Ben de iki gruba da girmeyince ortada kaldım. O dönemde de şeydi dediğim gibi internette çok az olduğu için etkinlikleri çok vermek istemiyorlardı mesela. Paylaşım noktasında çok eksikler vardı. Öğretmenler arasında bir de çok fazla rekabet vardı. Ben en iyi olmak istiyorum, bu okulun en iyi öğretmeni ben olmalıyım rekabeti çok fazlaydı. Bu süreç de ister istemez yıpratıyordu. (Ö18 kodlu öğretmen)

Okul öncesi öğretmenlerinin mesleğe ilk başladıklarında yaşadıkları sorunlardan “okul yönetimi/yönetimsel sorunlar” alt temasına yönelik örnek ifadeler şu şekildedir:

İlköğretim bünyesinde bir anasınıfında öğretmen olduğum için olsa gerek benim bölümüm okul idaresi tarafindan önemli görülmüyordu. Biz okulun içinde kenarda, kıyıda, köşede kalmış bir haldeydik. İsteklerimiz idare tarafından yapılmaya çalışılıyordu ama çok da önemli olarak değerlendirilmiyordu. Anlaşılamıyorduk. Kendinizi bir İngilizce öğretmeni kadar değerli hissedemiyorsunuz çünkü onlar öğrencilerini bir sınava hazırlıyorlar ve daha önemli bir meslekmiş gibi gözüküyordu. Bu konuda da baya üzüntü yaşadım. (Ö9 kodlu öğretmen)

Gezici anaokulu kalktıktan sonra kurumda görev yapmaya başladım. İlk başta üç arkadaş başlamıştık ve demiştim ikisi Yozgatlıydı. Mobil anaokuluna öğretmen tercih edilirken öncesinde gönüllü olup olmadığ 1 sorulabilirdi. Hiç sorulmadan ve benim düşüncem alınmadan dışarıdan geldiğim için direk bana verildi ki ben uzun yolu fizyolojik olarak çok kaldıramıyorum. Yol beni tutar mesela. Bunların dikkate alınması gerekiyordu. (Ö16 kodlu öğretmen)

Okul öncesi öğretmenlerinin mesleğe ilk başladıklarında yaşadıkları sorunlardan "çocuklar ile ilgili yaşadıkları sorunlar" alt temasına yönelik örnek ifadeler şu şekildedir: "En büyük sorunlarımdan bir tanesi dil problemiydi. Çocuklarla hiçbir şekilde anlaşamıyordum. Özellikle küçük yaş, 3 yaş grubunda.” (Ö1 kodlu öğretmen)

En büyük yaşadığım sorunlardan biri çocukların dilinin farklı olmasıydı. Ben okul öncesi eğitim programını uygulayacaktım ama çocuk programdan ziyade Türkçe'yi bilmiyordu. Bu noktada o programı tamamen kaldırdım ben ve artık çocuklara Türkçe öğretmeye başladım. Yaşadığım en büyük sorun buydu. (Ö2 kodlu öğretmen) 
Öğretmenliğe ilk atandığımda çok heyecanlıydım. Ama bir köy okuluna atandığım için de açıkçası biraz korkuyordum. Nasıl yapabilirim, yeterli malzeme var mıdır, çocuklar Türkçe biliyor mudur, iletişime geçebilir miyim? gibi sorular beni korkutuyordu. Ve korktuğum her şey ile de karşılaşıtım. Bir sınıf yoktu. Hiç bir materyal ve malzeme yoktu. Çocuklar okula severek gelmiyorlardı ve ayrıca Türkçe bilmiyorlardı. (Ö10 kodlu öğretmen)

Okul öncesi öğretmenlerinin mesleğe ilk başladıklarında yaşadıkları sorunlardan "veliler ile ilgili yaşadıkları sorunlar" alt temasına yönelik örnek ifadeler şu şekildedir:

Fiziksel ortam ile ilgili hiçbir problem yoktu. Benim sınıfımı AÇEV kurmuştu zaten. Gayet donanımlı bir sınıftı köy okulunda olmama rağmen. Ama tabi ki veliler çok bilinçli olmadıkları için onlarla iletişim konusunda problemler yaşıyordum. Hani sadece çocuğu okula gönderiyorlardı ve onun dışında veliyi göremiyordum, iletişim kuramıyordum veya anlattığım bir şeyi çok fazla anlamıyorlardı. (Ö7 kodlu öğretmen)

Bunun dişında aileler okul öncesi eğitimi sadece çocuk okula erken kalkmaya alışıyor düşüncesiyle gönderiyorlardı. O tabuları yıkmak için uğraştım ve dönemin sonunda veliler çocukların yaptığı portfolyo dosyalarını görünce velilerin çok hoşuna gitti. "Aa benim çocuğum bunları yapabiliyormuş” dediler. (Ö15 kodlu öğretmen)

Okul öncesi öğretmenlerinin mesleğe ilk başladıklarında yaşadıkları sorunlardan "toplum ile ilgili yaşadıkları sorunlar" alt temasına yönelik örnek ifadeler şu şekildedir:

Köyde ilk defa okul öncesi açılmıştı, hiç bilmiyorlardı okul öncesini ve garip bakıyorlardı. Köylü çok ilginç karşı1lyordu. Hatta köylünün biri geldi dedi ki "hoca hanım iyi ki açtınız şu sınıfı" dedi hatta "biz tarlaya giderken çocukları bırakacak adam bulamıyorduk" dedi. (Ö3 kodlu öğretmen)

Öğretmenliğe başladığımda benim yaşayacağımı tahmin ettiğim sorun erkek anasınıfı öğretmeni olur muydu; cinsiyetle alakalı. İlk defa benim atandığım ilçeye bir erkek okul öncesi öğretmeni atanmış. Daha önce böyle bir yaşantısı yok insanların. Hep soruyorlardı işte erkek öğretmenlerden de anasınıfı öğretmeni oluyor mu diye. (Ö4 kodlu öğretmen)

Okul öncesi öğretmenlerinin mesleğe ilk başladıklarında yaşadıkları sorunlardan "diğer yaşadıkları sorunlar" alt temasına yönelik örnek ifadeler şu şekildedir:

Ayrıca ilk atandığımda "Hazırlayıcı ve Temel Eğitimi”" verildi, bu eğitimi sabah saat sekizden akşam saat beşe kadar bir süre boyunca verdiler. Bu eğitimi aldığımız süre boyunca çocuklardan ayrı kaldık, biz eğitimde olduğumuz için çocuklar da okula gelemediler. Bu durum bence önemli bir 
hataydı. Kısa bir süre oldu ama yanlış bir uygulamaydı. (Ö5 kodlu öğretmen)

Bunun dişında bir de ulaşım konusunda problem yaşıordum. Köy okulundaydım, ilçede seminerler oluyordu. İlçeye gidip gelmem için özel araç kiralamam gerekiyordu yani taksi ile gidiş-geliş yapıyordum. Herhangi bir servis veya ilçe milli eğitimden herhangi bir tolerans tanınmıyordu. Hani gitmek zorundayım ve her seferinde özel araçla gidip geliyordum. (Ö7 kodlu öğretmen)

\section{Dördüncü Alt Probleme İlişkin Araştırma Bulguları}

Okul öncesi öğretmenlerinin meslek yaşantılarının ilk yıllarında yaşadıkları sorunların üstesinden gelme yöntemleri Tablo 5’te verilmiştir.

Tablo 5

Okul Öncesi Öğretmenlerinin Meslek Yaşantılarının İlk Yıllarında Yaşadıkları Sorunların Üstesinden Gelme Yöntemleri

\begin{tabular}{llc}
\hline Tema & Kodlar & f \\
\hline & Kısa süreli öğretmenlik deneyimlerinden & 9 \\
& Kuramsal bilgileri ve kısa süreli öğretmenlik deneyimlerinin bir & 7 \\
& arada kullanılmasından & \\
Mücadele & Deneyimli meslektaşlardan & 7 \\
Yöntemleri & Lisans yıllarındaki kuramsal bilgilerden & 3 \\
& İnternetten & 3 \\
& Kaynak kitaplardan & 1 \\
& Lisans eğitimleri sürecinde ders almış oldukları öğretim üyelerinden & 1 \\
& Seminer, konferans, hizmet içi eğitim ve kurslardan & 1 \\
& Rehberlik uzmanlarından & 1 \\
\hline
\end{tabular}

Tablo 5'ten okul öncesi öğretmenlerinin meslek yaşantılarının ilk yıllarında yaşadıkları sorunların üstesinden gelme yöntemleri incelendiğinde, öğretmenlerin anlatılarından en fazla mesleğe başladıklarında edindikleri kısa süreli öğretmenlik deneyimlerinden yararlandıkları $(\mathrm{n}=9)$ anlaşılmıştır. Bunun yanında öğretmenlerin yaşadıkları sorunlar karşısında deneyimli meslektaşlarına $(\mathrm{n}=7)$, kuramsal bilgileri ve kısa süreli öğretmenlik deneyimlerini bir arada kullanılmasına $(\mathrm{n}=7)$, lisans yıllarında edindikleri kuramsal bilgilere $(n=3)$, internete $(n=3)$, lisans eğitimleri sürecinde ders almış oldukları öğretim üyelerine $(n=1)$, seminer, konferans, hizmet içi eğitim ve kurslardan edindikleri bilgilere $(\mathrm{n}=1)$ ve rehberlik uzmanlarına $(\mathrm{n}=1)$ başvurdukları görülmektedir.

Okul öncesi öğretmenlerinin ilk yılki mesleki yaşantılarında karşılaşmış oldukları sorunlarla başa çıkmada başvurdukları yollara ilişkin örnek ifadeler şu şekildedir: 
Tabi ki lisans yıllarında edindiğim öğretmenlik meslek bilgilerimden de faydalandım ama insanların desteği de oldu. Yine diyorum okul müdürüm çok iyiydi çok fazla destek oldu. Onun haricinde üniversiteden hocam vardı, Işıı hoca, hala şuan görev yapıyor. Onunla istişare içindeydim. İşte mesela bir müfettişle tanışıım orada, onunla konuştum, onun çok faydaları oldu bana. O şekilde bir şeylerin üstesinden geldim. (Ö2 kodlu öğretmen)

Valla ikisinden de faydalandım. Tek birisi oldu desem olmaz, ikisi birbiriyle bir bütün. Öğretmenlik meslek bilginiz yeterli olabilir ama deneyim olmadan da başarıya ulaşamazsınız. Mutlaka ikisi bir olmalı. İkisinden de faydalandım ben. Bunun yanında tabi arkadaş çevremden bilgi alışverişi yapıyorduk. Biz o sene otuz okul öncesi öğretmeni atanmıştık. Onlarla bilgi alışverişi yapıyorduk, yeri geliyor internetten araştırıyorduk. (Ö9 kodlu öğretmen)

\section{Beşinci Alt Probleme İlişkin Araştırma Bulguları}

Okul öncesi öğretmenlerinin ilk yıllarda yaşadıkları sorunlardaki değişim durumu Tablo 6'da verilmiştir.

Tablo 6

Okul öncesi öğretmenlerinin ilk yllki mesleki yaşantılarında karşılaştıları sorunlardaki değişim durumu

\begin{tabular}{|c|c|c|c|}
\hline Tema & Alt Tema & Kodlar & f \\
\hline \multirow{14}{*}{ 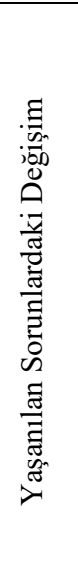 } & & Öğretmenlik meslek becerileri ile ilgili sorunlar & 11 \\
\hline & & Mobilya ve materyal eksiklikler & 5 \\
\hline & Zamanla & Çocukların anadillerinin farklı olması & 5 \\
\hline & Azalip & Ebeveynlerin okul öncesi eğitiminin önemi hakkındaki & 2 \\
\hline & Kaybolan & farkındalıklarının yetersiz düzeyde olması & \\
\hline & Sorunlar & Ebeveynlerin eğitim sürecine katılımlarının yetersiz olmas1 & 1 \\
\hline & & n yönetiminin anasınıflarını önemli görmemesi & 1 \\
\hline & & $\begin{array}{l}\text { "Erkek okul öncesi öğretmeni olmaz" düşüncesinin hakim } \\
\text { olmas1 }\end{array}$ & \\
\hline & & Okul binasının fiziksel koşullarının uygun olmaması & 2 \\
\hline & & Cocuk sayısına göre metrekaresi küçük bir sınıfa sahip olunması & 1 \\
\hline & Devam & & 1 \\
\hline & Eden & Okul öncesi öğretmenlerinin "bakıcı" olarak algılanması & 1 \\
\hline & Sorunlar & Ebeveynlerin okul öncesi eğitiminin önemi hakkındaki & 1 \\
\hline & & $\begin{array}{l}\text { farkındalıklarının yetersiz düzeyde olma } \\
\text { Cocukların anadillerinin farklı olması }\end{array}$ & 1 \\
\hline
\end{tabular}

Tablo 6 incelendiğinde okul öncesi öğretmenlerinin ilk yıllarda yaşadıkları sorunlardaki değişim durumu "zamanla azalıp kaybolan sorunlar" ve "devam eden sorunlar" olmak üzere iki alt tema altında incelenmiştir. Öğretmenlerin ilk yıllardaki mesleki yaşantılarında karşılaşıkları sorunlardan öğretmenlik meslek becerileri ile ilgili yaşadıkları sorunların $(\mathrm{n}=11)$ çoğunlukla zamanla azalıp kaybolan sorunlardan 
olduğu görülmüştür. Bunun yanında mobilya ve materyal eksiklikleri $(\mathrm{n}=5)$, çocukların anadillerinin farklı olması $(n=5)$, ebeveynlerin okul öncesi eğitiminin önemi hakkındaki farkındalıklarının yetersiz olması $(n=2)$, ebeveynlerin eğitim sürecine katılımlarının yetersiz olması $(n=1)$, ilköğretim yönetiminin anasınıflarını önemli görmemesi (n=1) ve "erkek okul öncesi öğretmeni olmaz" düşüncesinin hakim olması $(\mathrm{n}=1)$ diğer zamanla azalıp kaybolan sorunlar arasında yer almaktadır. Öğretmenlerin ilk yılki mesleki yaşantılarında karşılaştıkları sorunlardan olan okul binasının fiziksel koşullarının uygun olmaması $(\mathrm{n}=2)$, çocuk sayısına göre metrekaresi küçük bir sınıfa sahip olunması ( $\mathrm{n}=1)$, okul öncesi öğretmenlerinin "bakıcı" olarak algılanması $(\mathrm{n}=1)$, ebeveynlerin okul öncesi eğitiminin önemi hakkındaki farkındalıklarının yetersiz düzeyde olması $(n=1)$, çocukların Türkçelerinin kendilerinin ifade edebilmelerindeki yetersizliği $(n=1)$ ve mobilya/materyal eksikliklerinin olması $(\mathrm{n}=1)$ ise devam eden sorunlar olarak belirtilmiştir. Bu bulgular incelendiğinde bazı öğretmenler için çocukların Türkçelerinin kendilerinin ifade edebilmelerindeki yetersizliği ve mobilya/materyal eksikliklerinin olması sorunları zamanla azalıp kaybolan sorunlar iken bazı öğretmenler için devam eden sorunlar arasinda olduğu görülmektedir.

Okul öncesi öğretmenlerinin mesleğe ilk başladıklarında karşılaştıkları sorunlardaki değişim durumlarından "zamanla azalıp kaybolan sorunlar" alt temasına yönelik örnek ifadeler şu şekildedir:

Zaman içerisinde sorunlar giderek azaldı. Mesela şive sorunları giderek düzeldi. Çocuklara öğrettiğim şiir, şarkı, tekerlemeler, hikayeler gibi ana dil etkinlikleri çocukların dil gelişiminde çok büyük yollar kat etmemizi sağladı. (Ö15 kodlu öğretmen)

Dediğim gibi genelde tecrübe eksikliğine bağlı sınıf yönetimi konusunda sıkıntılar yaşamışıım. Dediğim gibi bu sorunun üstesinden de yaklaşık bir ay içerisinde üstesinden geldim. Çocukları tanıdıkça onlarla iletişim kurma noktasında kendimi daha geliştirdim bu durum da sınıf yönetimi becerilerime olumlu yönde yansıdı. (Ö13 kodlu öğretmen)

Malzeme, materyal velilerden aldığımız paralarla, aidatlarla, okul müdürlüğünün, milli eğitim müdürlüğünün yaptıkları yazılı talepler doğrultusunda karşılandı. Zaten çok fazla bir beklentiniz de olmuyor. Diğer konu okul öncesinde erkek anasınıfi öğretmeni olur mu problemi hiç problem olmadı. Veliler çok çabuk kabul ettiler. Ben bir de şuna bağlıyorum. Bulunduğunuz ortamın sosyo-kültürel yapısıyla çatışmadığınız müddetçe veliler sizi cinsiyet konusunda hiç sıkıntıya sokmuyor. Tamamen aştık bu sorunları zamanla. Cinsiyetle ilgili problemi hızlı aştık sadece espri konusu oluyordu anasınıfı değil babasınıfı, anaokulu değil babaokulu diye. (Ö4 kodlu öğretmen) 
Okul öncesi öğretmenlerinin mesleğe ilk başladıklarında karşılaştıkları sorunlardaki değişim durumlarından "devam eden sorunlar" alt temasına yönelik örnek ifadeler şu şekildedir:

Fiziki koşullar ile ilgili yaşadığım sorunlar aynı kaldı çünkü okulun fiziki yapısı bu şekildeydi ve yapacak bir şey yoktu. Ama çocukların uyum problemleri giderek azaldı. Bana alıştılar, ben onlara alıştım. (Ö19 kodlu öğretmen)

Veliyle görüşmelerimiz zaman içinde yine olmadı. Öğretmene saygı vardı ama okul öncesi eğitim onlar için maalesef o kadar önemli değildi. Ne kadar önemli olduğunu anlatmaya çalışsam da bu konuda başarılı olmadım. Çocukları sınıflara kaydetmemiz zor oluyordu. Çocukların devamını sağlamamız zor oluyordu. (Ö12 kodlu öğretmen)

\section{Altıncı Alt Probleme İlişkin Araştırma Bulguları}

Okul öncesi öğretmenlerinin ilk yıllardaki mesleki yaşantılarının onların mesleki gelişimine katkısı Tablo 7'de sunulmuştur.

\section{Tablo 7}

Okul Öncesi Öğretmenlerinin İlk Yılki Mesleki Yaşantılarının Onların Mesleki Gelişimine Katklsı

\begin{tabular}{llc}
\hline Tema & Kodlar & f \\
\hline & Veli ile etkili iletişim kurabilme & 12 \\
& Çocuklarla etkili iletişim kurabilme & 5 \\
& Sinıf yönetimini sağlayabilme & 3 \\
& Deneyimli bir öğretmen olma yolunda ilerleme & 3 \\
Öğretmene & Uyum haftasına yönelik deneyim kazanma & 2 \\
Katkısı & Eldeki olanakları değerlendirebilme & 2 \\
& Çevredeki firsatları kullanabilme & 2 \\
& Okul öncesi öğretmenin dosyasında bulundurması gereken & 2 \\
& evrak ve dokümanları öğrenme & 1 \\
& Çocukları tanıma ve değerlendirmede deneyim kazanma & 1 \\
& Öğrenme sürecine uygun yöntem ve teknikleri tercih edebilme & 1 \\
& Okul öncesi eğitimle ilgili mevzuat ve yönetmelikleri öğrenme & 1 \\
\hline
\end{tabular}

Okul öncesi öğretmenlerinin ilk yıllardaki mesleki yaşantılarının onların mesleki gelişimine katkısı Tablo 7'den incelendiğinde, bu ilk yıllardaki mesleki yaşantının öğretmenlere özellikle veli ile etkili iletişim kurabilme $(n=12)$ konusunda katkısının olduğu görülmüştür. Bunun yanında bu ilk yıllardaki mesleki yaşantıların çocuklarla etkili iletişim kurabilme $(n=5)$, sınıf yönetimini sağlayabilme $(n=3)$, deneyimli bir öğretmen olma yolunda ilerleme $(n=3)$, uyum haftasına yönelik deneyim kazanma $(n=2)$, eldeki olanakları değerlendirebilme $(n=2)$, çevredeki firsatları kullanabilme $(n=2)$, okul öncesi öğretmenin dosyasında bulundurması gereken evrak ve dokümanları öğrenme $(n=2)$, çocukları tanıma ve değerlendirmede deneyim kazanma 
$(\mathrm{n}=1)$, öğrenme sürecine uygun yöntem ve teknikleri tercih edebilme $(\mathrm{n}=1)$ ve okul öncesi eğitimle ilgili mevzuat ve yönetmelikleri öğrenme $(n=1)$ konularında öğretmenlerin mesleki gelişimine katkısı olduğu görülmektedir.

Okul öncesi öğretmenlerinin ilk yılki mesleki yaşantılarının onların mesleki gelişimine katkısına yönelik örnek ifadeler şu şekildedir:

İlk yıl deneyimleri tabi ki diğer yıl için bir tecrübe oluşturdu ve daha rahat hareket etmemizi sağladı. Velilerle, çocuklarla iletişimde, çocukların daha iyi nasıl öğrenecekleri ve yapılacak etkinliklerdeki uygulanacak yöntemin nasıl daha etkili olacağı ile ilgili elde edindiğim ilk yılki tecrübelerimi ikinci yıla aktardım. (Ö5 kodlu öğretmen)

Okul öncesi eğitimde öğretmen-veli ilişkileri oldukça önemli. İlk yıl özellikle veli ile olan ilişkilerin önemli olduğunu öğrendim. Büyük sınıflarda çocuklar okula gelir, veli ise sadece sorun olduğunda okula gelirdi ama bizim yaş grubunda her zaman veli ile muhatapsınız. Sabah bırakmaya gelir öğlen almaya gelir. Böylece veli geldiği zaman çocuğu ile ilgili sorularda sorar. İşte yemeğini yedi mi, kahvaltısını yaptı mı? gibi. Bunlara doğru cevap vermeniz gerekli. Birebir veliyle ilişki içinde olmanız gerekiyor. Dolayısıyla bu noktada sadece çocuklarla alakalı sorunların değil velilerle alakalı durumlarla ilgili de hazırlıklı olunması gerektiğini öğrenmiştik. (Ö4 kodlu öğretmen)

\section{Tartışma, Sonuç ve Öneriler}

Öğretmenlik mesleği genel yeterlikleri çerçevesinde öğretmenin olumlu kişilik yapısına sahip, bilimsel ve bireysel gelişime açık ve bunun yanında öğretmenlik meslek becerilerinde yetkin olması gerekmektedir. Öğretmenin bu yeterliklere sahip olmasında ise öğretmen yetiştirme sorumluluğunu üstlenen üniversite eğitim fakültelerinin önemli bir işlevi bulunmaktadır. Öğretmen yetiştirme sürecinde eğitim fakülteleri bilimsel birikimin öğretmen adaylarına aktarılması işlevini yerine getirirken öğretmenin sahip olması beklenen yeterliklere ulaşmasında öğretmen adaylarına uygulama deneyimleri de sunmaktadır. Öğretmen adayları ise lisans yıllarında edindikleri kuramsal bilgilerini ancak öğretmen olarak göreve başladıklarında tam anlamıyla deneyimleme firsatı bulabilmektedir. Bu bağlamda mesleki yaşantılarının ilk yıllarına ilişkin deneyimlerinin önemli görülmesi nedeniyle bu araşıırmada okul öncesi öğretmenlerinin meslek yaşantılarının ilk yıllarına ilişkin deneyimlerinin neler olduğu sözlü tarih yöntemi ile incelenmiştir.

Araştırma sonucunda okul öncesi öğretmenlerinin lisans öğrenimlerinin son yılında geleceğe yönelik beklentileri arasında en fazla öğretmen olarak atanabilmek arzusunda oldukları anlaşılmışıı. İlgili alanyazın incelendiğinde de araştırmanın bu bulgusunu destekleyen pek çok çalışmaya rastlanmıştır. Çalışmaların birinde bir üniversitenin son sınıf öğrencilerinin yaklaşık \% 27'sinin iş bulma kaygısı taşıdı̆̆ 1 belirtilmiştir (Gizir, 2005). Aynı durum farklı üniversitelerdeki öğrencilerle yürütülen çalışmalarda da belirlenmiş ve öğrencilerin çoğunluğunun mezun olduklarında iş 
bulma kaygısı taşıdıkları belirtilmiştir (Dereli ve Kabataş, 2009; Dursun ve Aytaç, 2009; Kıcır, 2010). Başka çalışmalarda da atanma kaygısının öğretmen adaylarının geleceğe ilişkin başlıca stres kaynağı olduğu görülmektedir (Akpınar, 2013; Aslan, 2010; Üstün ve diğ., 2014; Şahin, 2011).

Öğretmen adaylarının gelecek beklentilerine yönelik gerçekleştirilmiş olan bazı çalışmalarda adayların çoğunluğunun öğretmenlik yapma arzusunda oldukları (Başkonuş, Akdal ve Taşdemir, 2011; Ekiz, 2006; Şahin, 2011) ve öğretmen olarak atanamamanın onların yaşamlarını çok olumsuz yönde etkileneceğini düşünmekte olduklarına rastlanmaktadır (Şahin, 2011). Bu bağlamda bu araştırmada elde edilen öğretmenlerin lisans öğrenimlerinin son yılında geleceğe yönelik beklentileri arasında en fazla Milli Eğitim Bakanlığı'na bağlı devlet okuluna kadrolu olarak atanma arzusunda olmaları bulgusu beklenen bir sonuç olarak karşımıza çıkmaktadır. Bunun yanında araştırmada öğretmenlerin lisans öğrenimlerinin son yılında geleceğe yönelik beklentilerinin sadece atanmayla sınırlı olmadığı anlaşılmaktadır. Öğretmelerin göreve atanmanın yanında çocukların gelişimine uygun nitelikli bir eğitim sunabilen, mesleğini severek yapan, yüksek lisans yaparak alanda kendini geliştiren, sabırlı, çocukları seven iyi bir öğretmen olabilme gibi geleceğe yönelik beklentilerinin de olduğu görülmüştür. İlgili alanyazındaki çalışmalar incelendiğinde; kariyer yapma (Başkonuş ve diğ., 2011; Ekiz, 2006), mesleğini severek yapma (Temizkan, 2008; Özçakmak ve Köroğlu, 2015), ögrencileri ile olumlu ilişkiler oluşturma (Özçakmak ve Köroğlu, 2015) öğretmen adaylarının geleceğe yönelik beklentileri arasındadır. Bunun yanında öğretmenlik mesleki gelişim süreci içerisinde birinci dönem olan mesleğe hazırlık döneminde bireylerin öğretmenlik mesleğine ilgi duyma nedenleri arasında kazanç sağlama, saygınlık ve iş güvenliği elde etme gibi maddi yararlar ile ahlaki değerlere katkı sağlayarak hizmet etmek gibi nedenlerin yer aldığ 1 görülmektedir (Lortie, 1975; akt. Aydın, 2018). Bu bağlamda bu araştırmada elde edilen öğretmenlerin lisans öğrenimlerinin son yılında geleceğe yönelik beklentilerinin çeşitli ve olumlu olması bulgusu ilgili alanyazın ile benzerlik göstermektedir. Öğretmenlerin geleceğe yönelik beklentileri arasında atanma arzusunun daha ön planda olması ise öğretmenlerin diğer tüm beklentilerini gerçekleştirebilmelerinin ancak atanma beklentisinin karşılanmasına bağlı olmasından kaynaklandığı düşünülebilir.

Okul öncesi öğretmenlerinin mesleğe başladıkları ilk yılın başlarında hissettikleri duygular incelendiğinde en fazla mutluluk, heyecan ve tedirginlik duygularını yaşamanın yanında hayal kırıklığı, korku, stres ve umutsuzluk duygularını hissettikleri görülmüştür. Ruohotie-Lyhty (2013) öğretmenlerin mesleki yaşantılarının ilk yıllarına ilişkin anlatılarına yönelik yaptığı çalışmasında da ilk yıl başında araştırmaya katılan öğretmenlerin tedirginlik, güvensizlik, şaşkınlık, hayal kırıklığ 1 ve stres duygu durumlarını hissettiklerini ortaya koymuştur. Öğretmenlerin mesleki deneyimleri üzerine yapılan diğer çalışmalarda da öğretmenlerin ilk yıllarda çeşitli konularda endişe, kaygı, stres, hayal kırıklı̆̆ı, yetersizlik gibi duygular hissettikleri görülmektedir (Ewing ve Smith, 2003; Manuel ve Brindley, 2002). Gençtürk ve Memiş (2010) öğretmenlerin öz yeterlik algıları üzerinde yürüttükleri 
çalışmalarında meslekteki kıdem yılının öğretmenlerin öz yeterlik algılarında önemli bir fark oluşturduğunu ortaya koymaktadır. Özellikle mesleki deneyimi fazla olan öğretmenlerin kendilerini öğrenci katılımında, uygun öğretimsel stratejiler geliştirme ve sınıf yönetimi alanlarında daha yeterli hissettikleri görülmektedir. Aynı şekilde öğretmenlerin öz yeterlik algıları üzerine yapılan diğer çalışmalar incelendiğinde de yine öğretmenliğin ilk yıllarında öğretmenlerin kendilerini daha deneyimsiz hissettiklerini ortaya koyan sonuçların olduğu görülmektedir (Daugherty, 2005; Meziroğlu, 2005; Say, 2005). Diğer bir deyişle deneyimli öğretmenler zaman içerisinde etkili öğretimsel stratejiler ve sınıf yönetimi becerileri geliştirme olanağ 1 bulmuş ve daha yetkin duruma gelmişlerdir (Tschannen-Moran ve Woolfolk-Hoy, 2002). Bu bağlamda bu araştırmada elde edilen okul öncesi öğretmenlerinin mesleğe başladıkları ilk yıl hissettikleri olumsuz duyguların mesleki yaşantılarının başlangıcında olmaları ile doğrudan ilgili olduğu düşünülebilir. Öğretmenlerin lisans yıllarında edindikleri kuramsal bilgileri lisans yılları içerisinde uygulama deneyimleri ile bütünleştirme deneyimlerinin az olması, mesleğin ilk yıllarında kendilerini deneyimsiz olarak değerlendirmelerine ve böylece olumsuz duygulara kapılmalarına neden olabildiği düşünülebilir.

$\mathrm{Bu}$ araştırmada elde edilen diğer önemli bir bulgu ise okul öncesi öğretmenlerinin mesleğe ilk başladıklarında çeşitli sorunlar yaşamaları olmuştur. Ögretmenlerin yaşadıkları bu sorunlar incelendiğinde; bunların eğitim ortamı, öğretmenlik meslek becerileri, meslektaş, okul yönetimi, çocuklar, veliler ve toplum ile ilişkili olduğu görülmektedir. İlgili alanyazına bakıldığında da öğretmenlik mesleğinin ilk yllının genellikle öğretmenlik meslek kariyerinin en zor yılı olduğu kabul edilmektedir (Fullan, 2007). Aynı zamanda öğretmenlik mesleğinin ilk yılında öğretmenlerin ortak bazı sorunlar ve zorluklar yaşadıkları anlaşılmaktadır (Heick, 2018; Olson ve Osborne, 1991; Veenman, 1984). Yalçınkaya (2002) mesleğe yeni başlayan öğretmenler için deneyimsizlik, mesleki sorumlulukların üstesinden gelememe, okul ve çevreye uyumda zorlanma durumlarının en sık yaşanan sorunlar olduğunu belirtmektedir. Mesleğe yeni başlayan öğretmenlerin çoğunlukla hayal kırıklı̆̆ı, kuşku, endişe ve suçluluk gibi olumsuz duygulanım yaşadıkları görülmektedir (Roehrig ve diğ., 2002). Öğretmenliğin ilk yıllarında yaşanan zorluklara ilişkin yürütülen bir diğer çalışmada ise çocukların farklı gelişimsel gereksinimlerini anlamada, materyal ve kaynakların yetersiz olması, bireyselleştirilmiş eğitim programı oluşturmada zorlanma, iki dilli öğrencilerle çalışmada yetersiz kalma, sınıf yönetimi, öğretmen ücretlerinin düşük olması, yönetici, öğretmen, ebeveyn ve meslektaşlarıyla olumlu etkileşimler oluşturmada zorlanma gibi konularda sorunlar yaşadığı anlaşılmaktadır (Fantilli ve McDougall, 2009, Kozikoğlu ve Senemoğlu, 2018). Bunun yanında toplum tarafindan gerekli değeri görmede ve farklı kültürden gelen öğrencilerle ilgilenmede güçlüklerle karşılaşılması öğretmenlerin diğer yaşadığı sorunlar arasında olduğu görülmektedir (Ewing ve Smith, 2003; Güçlü, 2004; Johnston, 2002; Kozikoğlu ve Senemoğlu, 2018; Sünbül, 2005; Veenman, 1984). İlgili çalışmaların bulguları incelendiğinde öğretmenler tarafından genellikle sınıf yönetimi, hayal kırıklığı, endişe, yalnız kalma, 
mesleki sorumluluklar altında boğulma gibi olumsuz duygulanım yaşama, kendini deneyimsiz hissetme sıkça dile getirilen sorunlar olarak karşımıza çıkmaktadır. Bu araştırmada öğretmenlerin dile getirdiği sorunların da diğer çalışmalardan elde edilen araştırma bulguları ile benzer olduğu görülmektedir. Öğretmenlerin benzer sorunlar yaşamasının kaynağı mesleğin ilk yıllarında öğretmenlerin deneyimsiz olmaları olarak düşünülebilir.

Okul öncesi öğretmenlerinin ilk yıllarındaki öğretmenlik meslek deneyiminde yaşadıkları sorunlarla baş etme yöntemleri incelendiğinde öğretmenlerin en fazla mesleğe başladıklarında edindikleri kısa süreli öğretmenlik deneyimlerinden yararlandıkları görülmüştür. Bunun yanında öğretmenlerin yaşadıkları sorunlar karşısında deneyimli meslektaşlarına, lisans yıllarında edindikleri kuramsal bilgilere, internete, lisans öğrenimleri sürecinde ders almış oldukları öğretim üyelerine, seminer, konferans, hizmet içi eğitim ve kurslardan edindikleri bilgilere ve rehberlik uzmanlarına başvurdukları görülmüştür. İlgili alanyazın incelendiğinde öğretmenlerin mesleki yaşantılarında deneyim kazandıkça mesleki yeterlik açısından kendilerini daha donanımlı hissettikleri görülmektedir (Gençtürk ve Memiş, 2010; Meziroğlu, 2005; Say, 2005; Tan, 2000). Bu bağlamda öğretmenlerin karşılaştıkları sorunlarla baş etmede öncelikli olarak kendi öğretmenlik deneyimlerinden yararlanmaları beklenen bir sonuç olarak karşımıza çıkmaktadır. Bunun yanında alanda daha deneyimli bir kişiden destek almak ise öğretmenlik mesleğinin ilk yılında yaşanacak sorunları ortadan kaldırmada önemli bir etken olarak ele alınmaktadır (Ewing ve Smith, 2003). Bir öğretmenin deneyimli bir öğretmenden destek alması o öğretmenin zorlukların üstesinden gelmesinde işini kolaylaştırmaktadır (Conderman ve Stephens, 2000). Bu bağlamda öğretmenlerin karşılaştıkları sorunlar karşısında daha deneyimli meslektaşlarına, lisans öğrenimleri sürecinde ders almış oldukları öğretim üyelerine ve rehberlik uzmanlarına başvurmaları beklenen bir sonuç olarak ortaya çıkmaktadır.

Bunlara ek olarak araştırmada okul öncesi öğretmenlerinin ilk yıllarda yaşadıkları sorunlardaki değişim durumu da incelenmiş ve kendi ifadelerine dayalı olarak yaşadıkları sorunlardaki değişimin "zamanla azalıp kaybolma" ve "devam etme" şeklinde olduğu görülmüştür. Öğretmenlerin ilk yıllarındaki mesleki yaşantılarında karşılaştıkları öğretmenlik meslek becerileri ile ilgili olanların çoğunlukla zamanla azalıp kayboldukları görülmekle beraber; ebeveynlerin eğitim sürecine katılımlarının yetersiz olması, ilköğretim yönetiminin anasınıflarını önemli görmemesi ve "erkek okul öncesi öğretmeni olmaz" düşüncesinin hakim olması gibi durumların diğer zamanla azalıp kaybolan sorunlar arasında yer aldığı görülmüştür. Öğretmenlerin zaman ilerledikçe mesleki deneyimlerinin artmasına bağlı olarak mesleki yeterlikleri gelişmektedir. Bu nedenle özellikle öğretmenlik meslek becerileri ile ilgili yaşadıkları sorunların zamanla azalıp kaybolması beklenen bir sonuçtur. Bunun yanında öğretmenlerin ilk yıllardaki mesleki yaşantılarında karşılaştıkları sorunlardan olan okul binasının fiziksel koşullarının uygun olmaması, çocuk sayısına göre metrekaresi küçük bir sınıfa sahip olunması gibi sorunların devam ediyor olduğu anlatılarda anlaşılmaktadır. Özellikle fiziksel koşullarla ilgili karşımıza çıkan 
sorunların çözümü öğretmenlerden bağımsız çeşitli değişkenlerden kaynaklı devam etmektedir. Bu durumun da beklenen bir sonuç olduğu düşünülmektedir.

Sonuç olarak okul öncesi öğretmenlerinin lisans yıllarının sonunda atanma kendileri için en önemli durum olarak değerlendirilebilir. Buna ek olarak mesleğe atandıklarında çocukları ve mesleğini seven, başarılı bir öğretmen olmak istedikleri anlaşılmış̧ır. Mesleğe atandıklarında mutluluk ve heyecan duygularını hissetmekle birlikte aynı zamanda ilk yılın başında hayal kırıklığı, korku ve tedirginlik gibi duyguları da yaşadıkları anlatılarda ortaya çıkmıştır. Okul öncesi öğretmenlerinin mesleğe başladıkları ilk yıllarda fiziksel koşullar, öğretmenlik meslek becerileri, meslektaşları ve yönetim ile ilgili çeşitli sorunlar yaşadıklarına rastlanmıştır. Okul öncesi öğretmenlerin yaşadıkları bu sorunlarla baş etmede en çok kısa süreli öğretmenlik deneyimlerinden yararlandıkları anlaşılmış̧ır. Son olarak ilk yıllardaki deneyimlerin öğretmenlere özellikle veli ve çocukla etkili iletişim kurma, sınıf yönetimi ve deneyim kazanma konularında katkı sağladığı sonucuna ulaşılmıştır.

Araştırmanın bu sonuçları dikkate alındığında üniversite lisans eğitimi sürecinde yer alan öğretmenlik uygulaması dersinin uygulama süresinin arttırılması yoluyla öğretmen adaylarının mesleki becerilerinin daha iyi düzeye ulaşması sağlanabilir. Böylece öğretmen adaylarının mesleğe ilk atandıklarında mesleki anlamda kendilerine olan güvenleri daha yüksek olabilir. Öğretmenlerin çalıştığı okulların koşullarının ve sınıf öğrenci sayılarının (mevcutlarının) yönetmeliğe uygun olarak düzenlenmesi sağlanmalı ve bu doğrultuda denetleme süreçleri daha etkili olmalıdır. Böylece okulların fiziki koşulları daha iyi düzeye getirilebilir. Bununla birlikte öğretmenlere sağlanan hizmet öncesi eğitimlerin kapsamının öğretmenlerin ilk yıllarda yaşadıkları sorunlara özgü ve mesleğe geçişlerini kolaylaştırıcı nitelikte olmasına önem verilmesi, öğretmenlerin mesleğin ilk yıllarında yaşadıkları sorunların üstesinden gelebilmelerinde yararlı olabilir. Aynı zamanda öğretmenler arasında mesleki bilgi alışverişi, deneyim paylaşımı gibi mesleki verimi arttırabilecek ilişkiler sağlayabilmek için öncelikle öğretmenlerde mesleki doyum sağlamaya yönelik çalışma ortamı oluşturulmasının olumlu okul iklimi oluşturmada etkili olacağ düşünülebilir. Eğitimin önemli paydaşlarından biri olan velilere de yeterli ve kapsayıcı düzeyde seminer, konferans vb. çalışmalarla eğitimler verilmesi okul öncesi eğitiminin bileşenleri arasında olumlu bir bilgi akışı ve ilişkinin gelişimine katkı sağlayabilir.

\section{Etik Kurul Kararı}

$\mathrm{Bu}$ araştırma makalesi 19-22 Haziran 2019 tarih aralı̆̆ında Ankara Üniversitesi'nde düzenlenen VIth International Eurasian Educational Research Congress'de sözlü bildiri olarak sunulmuş olup belirtilen tarihte yapılan araştırmalar için etik kurul izni zorunlu olmadığından bu araştırmanın etik kurul izni bulunmamaktadır. 


\section{Kaynakça}

Afşin, F. N. (1988). Stajyer öğretmenlerin meslekle ilgili sorunlar ve çözüm yollar (Yayınlanmamış yüksek lisans tezi). https://tez.yok.gov.tr adresinden erişilmiş̧ir (Tez No. 4560).

Akpınar, B. (2013). Öğretmen adaylarının stres düzeylerinin çeşitli değişkenler açısından incelenmesi. Dicle Üniversitesi Ziya Gökalp Eğitim Fakültesi Dergisi, 21, 229-241. https://dergipark.org.tr/en/download/article-file/786880 adresinden erişilmiştir.

Aktankerem, E. ve Cömert, D. (2006). Siirt ilinde okul öncesi eğitim sorunlarının tespitine yönelik öğretmen görüşlerinin incelenmesi. Milli Eğitim Dergisi, 34 (170), 1-16. https://dergipark.org.tr/en/pub/milliegitim/issue/36942/422509 adresinden erişilmiştir.

Angrist, J. D., and Lavy, V. (2001). Does teacher training affect pupil learning? Evidence from matched comparisons in Jerusalem public schools. Journal of Labor Eonomics, 19(2), 343-369. Retrieved from https://www.researchgate.net/profile/Joshua_Angrist/publication/24099804_Do es_Teacher_Training_Affect_Pupil_Learning_Evidence_from_Matched_Comp arisons_in_Jerusalem_Public_Schools/links/53fb2b600cf20a4549704c91.pdf

Arat, Z. F. K. (2003). Where to look for the truth: memory and interpretation in assessing the impact of Turkish women's education. Women's Studies International Forum, 26 (1), 57-68. doi: 10.1016/S0277-5395(02)00355-2

Aslan, C. (2010). Türkçe öğretmenleri ve öğretmen adaylarının sorunları üzerine çevrimiçi paylaşım alanlarındaki (forum) iletilere dayalı bir çözümleme. NWSA: Education Sciences, 5(4), 2254-2269. https://dergipark.org.tr/tr/download/article-file/185770 adresinden erişilmiştir.

Aydın, İ. (2018). Teacher career cycles and teacher professional development Öğretmenlik kariyer evreleri ve öğretmenlerin mesleki gelişimi. Journal of Human Sciences, 15(4), 2047-2065. https://www.jhumansciences.com/ojs/index.php/IJHS/article/view/5450/2637 adresinden erişilmiştir.

Bağçeli-Karaman, P., Şen, T., Alataş, S. ve Tütüncü, B. (2018). Okul öncesi dönemde okula uyum sürecine ilişkin öğretmen görüşleri. Abant İzzet Baysal Üniversitesi Eğitim Fakültesi Dergisi, 18(2), 681-701. https://dergipark.org.tr/tr/download/article-file/485168 adresinden erişilmiştir.

Barnett, W. S. (1995). Long-term effects of early childhood programs on cognitive and school outcomes. The Future of children, 25-50. https://www.jstor.org/stable/1602366\#metadata_info_tab_contents adresinden erişilmiştir. 
Barrett, P. M., Cooper, M., and Teoh, A. B. (2014). When time is of the essence: a rationale for earlier early intervention. Journal of Psychological Abnormalities in Chidren, 3(4), 133-140. doi: 10.4172/2329-9525.1000133

Başaran, S., Gökmen, B. ve Akdağ, B. (2014). Okul öncesi eğitimde okula uyum sürecinde öğretmenlerin karşilaştiği sorunlar ve çözüm önerileri. Uluslararası Türk Eğitim Bilimleri Dergisi, 2014(2), 197-223. https://dergipark.org.tr/en/pub/goputeb/issue/7322/95820 adresinden erişilmiştir.

Başkonuş, T., Akdal, D. ve Taşdemir, M. (2011, Nisan). Ahi Evran Üniversitesi ĕğitim fakültesi son sınıf ögrencilerinin gelecek beklentileri. $2^{\text {nd }}$ International Conference on New Trends in Education and Their Implications kongresinde sözlü bildiri, Antalya. Tam metin http://www.iconte.org/FileUpload/ks59689/File/265_t_baskonus_vd..pdf adresinden erişilmiştir.

Başturan, C. (2018). Devlet ve özel okul öncesi eğitim kurumlarında görev yapan ögretmenlerin mesleki sorun tanımlarının incelenmesi. (Yayınlanmamış yüksek lisans tezi). https://tez.yok.gov.tr adresinden erişilmişstir (Tez No. 522056).

Bernard, H. R. (2011). Research methods in anthropology: Qualitative and quantitative approaches. Oxford, OX: AltaMira.

Bolich, A. M. (2001). Reduce your losses: Help new teachers become veteran teachers. Atlanta, GA: Southern Regional Education Board.

Brock, B. L., and Grady, M. L. (2005). Developing a teacher induction plan: A guide for school leaders. Thousand Oaks, California: Corwin Press.

Burke, P. J., Christensen, J. C., Fessler, R., Mcdonnell, J. H., and Price, J. R. (1987, April). The teacher career cycle: Model development and research report. Paper presented at the annual meeting of the American Educational Research Association, Washington.

Creswell, J. W. (2013). Research design: Qualitative, quantitative, and mixed methods approaches. Thousand Oaks, California: Sage.

Creswell, J. W., and Miller, D. L. (2000). Determining validity in qualitative inquiry. Theory into Practice, 39(3), 124-131. doi: 10.1207/s15430421tip3903_2

Clarke-Stewart, K. A. (1992). Consequences of child care for children's development. Alan Booth (Ed.), In Child Care in The 1990s: Trends and Consequences (pp. 63-82). Hillsdale, New Jersey: Lawrence Erlbaum Associates.

Conderman, G. and Stephens, J. T. (2000). Voices from the field: Reflections from beginning special educators. Teaching Exceptional Children, 33(1), 16-21. doi: 10.1177/004005990003300103 
Dağlığlu, H. E. (2012). Okul öncesi öğretmeninin özellikleri ve okul öncesi eğitime öğretmen yetiştirme. Gelengül Haktanır (Ed.). Okul Öncesi Eğitime Giriş içinde (ss. 39-80), Ankara: Anı Yayıncılık.

Darling-Hammond, L. (2000). Teacher quality and student achievement. Education Policy Analysis Archives, 8(1). 1-44. doi: 10.14507/epaa.v8n1.2000

Daugherty, S. G. (2005). Teacher efficacy and its relation to teachers' behaviors in the classroom (Order No. 3164986). Available from ProQuest Dissertations \& Theses Global. (305002473). Retrieved from https://search.proquest.com/dissertations-theses/teacher-efficacy-relationteachers-behaviors/docview/305002473/se-2?accountid=25247

Demircan-Aydın, Z. (2017). Öğretmen ve yöneticilerin okul öncesi eğitimi değerlendirmeleri ve bu alanda yaşanılan yönetimsel sorunlar. (Yayınlanmış yüksek lisans tezi). https://tez.yok.gov.tr adresinden erişilmiştir (Tez No. 477081).

Demirel, O. N. (1995). Öğretmenlik mesleğine yönelen eğitim fakültesi öğrencilerinin sosyo-ekonomik, psikolojik ve kültürel özellikleri üzerine bir araştırma. (Yayımlanmamış doktora tezi). https://tez.yok.gov.tr adresinden erişilmiştir (Tez No. 41910).

Dere, İ. ve Dinç, E. (2020). Sözlü tarihin geçerliliği ve güvenilirliği üzerine bir değerlendirme. Eskişehir Osmangazi Üniversitesi Sosyal Bilimler Dergisi, 21(2), 275-289. https://dergipark.org.tr/en/download/articlefile/1466164 adresinden erişilmiştir.

Dereli, F. ve Kabataş, S. (2009). Sağlık Yüksekokulu son sınıf öğrencilerinin iş bulma endişeleri ve umutsuzluk düzeylerinin belirlenmesi, Yeni Tıp Dergisi, 26, 31-36. https://s3.amazonaws.com/academia.edu.documents/38808948/1.pdf?responsecontent-disposition=inline\%3B\%20filename\%3Dhealth_literaty.pdf\&X-AmzAlgorithm=AWS4-HMAC-SHA256\&X-Amz-

Credential=AKIAIWOWYYGZ2Y53UL3A\%2F20200302\%2Fus-east1\%2Fs3\%2Faws4_request\&X-Amz-Date=20200302T113123Z\&X-AmzExpires $=3600 \& X-A m z-$ SignedHeaders $=$ host $\& X-A m z-$ Signature $=4 \mathrm{c} 73 \mathrm{~cd} 7 \mathrm{c} 31 \mathrm{a} 191471 \mathrm{bd} 430558329 \mathrm{~cd} 5770 \mathrm{f} 2155 \mathrm{~b} 96 \mathrm{~d} 30 \mathrm{c} 26852 \mathrm{ce} 7 \mathrm{ef}$ 1446dadc adresinden erişilmiştir.

Dursun, S. ve Aytaç, S. (2009). Üniversite öğrencileri arasında işsizlik kaygısı. Uludağ Üniversitesi İktisadi ve İdari Bilimler Fakültesi Dergisi, 28(1), 71-84. https://www.researchgate.net/profile/Salih_Dursun2/publication/293486658_U NIVERSITE_OGRENCILERI_ARASINDA_ISSIZLIK_KAYGISI/links/56b8 d01a08ae0a89c12f8c08/UeNIVERSITE-OeGRENCILERI-ARASINDAISSIZLIK-KAYGISI.pdf adresinden erişilmiştir. 
Doyle, W. (1986). Classroom Management Techniques. Oliver C. Moles (Ed.) Strategies to Reduce Student Misbehavior. Washington, DC: Office of Educational Research and Improvement.

Ekiz, D. (2006). Sınıf öğretmenliği mesleğine yönelen adayların profilleri ve geleceğe yönelik beklentilerinin incelenmesi. Firat Üniversitesi Sosyal Bilimler Dergisi, 16(1), 131-147. http://web.firat.edu.tr/sosyalbil/dergi/arsiv/cilt16/sayi1/131147.pdf adresinden erişilmiştir.

Ergenekon, Y. (2004). Işse yeni başlayan zihinsel özürlüler ögretmenlerinin mesleksel sorunlarının belirlenmesi ve bu sorunları gidermeye yönelik çözüm önerilerinin geliştirilmesi. (Yayınlanmamış doktora tezi). https://tez.yok.gov.tr adresinden erişilmiştir (Tez No. 143990).

Erdemir, N. (2007). Mesleğe yeni başlayan fen bilgisi öğretmenlerinin karşılaştıkları sorunlar ve şikâyetleri. Elektronik Sosyal Bilimler Dergisi 6(22), 135-149. https://dergipark.org.tr/en/pub/esosder/issue/6136/82299 adresinden erişilmiştir.

Erden, E. (2010). Problems that preschool teachers face in the curriculum implementation. (Yayınlanmamış yüksek lisans tezi). https://tez.yok.gov.tr adresinden erişilmiştir (Tez No. 263041).

Erkoç, A. (2010). Aday ögrretmenlerin göreve başladıklarında karşılaştıkları sorunlar. (Yayınlanmamış yüksek lisans tezi). https://tez.yok.gov.tr adresinden erişilmiştir (Tez No. 249606).

Ewing, R., and Smith, D. (2003). Retaining quality beginning teachers in the profession. English Teaching: Practice and Critique, 2(1), 15-32. Retrieved from

https://www.researchgate.net/profile/Robyn_Ewing/publication/239795949_Re taining_quality_beginning_teachers_in_the_profession/links/5448e95a0cf 2 f14f b814517b.pdf

Fantilli, R. D., and McDougall, D. E. (2009). A study of novice teachers: Challenges and supports in the first years. Teaching and Teacher Education, 25(6), 814-825. doi: 10.1016/j.tate.2009.02.021

Farrell, T. S. (2003). Learning to teach English language during the first year: Personal influences and challenges. Teaching and Teacher Education, 19(1), 95-111. doi: 10.1016/S0742-051X(02)00088-4

Fessler, R. (1992). The teacher career cycle. R. Fessler, \& J. C. Christensen (Eds.), In The teacher career cycle (pp. 21-44). Boston: Allyn and Bacon.

Flores, M. A. (2006). Being a novice teacher in two different settings: struggles, continuities, and discontinuities. Teachers College Record, 108(10), 2021-2052. doi: 10.1111/j.1467-9620.2006.00773.x 
Fullan, M. (2007). The New Meaning of Educational Change. Fourth Edition. New York: Teachers College Press.

Fuller, F. (1969). Concerns of teachers: a developmental conceptualization. American Educational Research Journal, 6(2), 207-226. doi: $10.3102 / 00028312006002207$

Fuller, F. F., and Bown, O. (1975). On becoming a teacher Teacher education, seventyfourth yearbook of the National Society for the Study of Education, part 2. Chicago: University of Chicago Press

Garmon, M. A. (1993, Nisan). Preservice teachers perception of the first year a teacher preparahon programme. The Annual Meeting of the American Educational Research Association Atlanta kongresinde sunulan sözlü bildiri. U. S. Michigan.

Gençtürk, A. ve Memiş, A. (2010). İlköğretim okulu öğretmenlerinin öz-yeterlik algıları ve iş doyumlarının demografik faktörler açısından incelenmesi. Ilköğretim Online, 9(3), 1037-1054. https://www.trdizin.gov.tr/publication/paper/detail/TVRFek16RTNOdz09 adresinden erişilmiştir.

Gizir, C. A. (2005). Orta Doğu Teknik Üniversitesi son sınıf öğrencilerinin problemleri üzerine bir çalışma. Mersin Üniversitesi Ĕ̈itim Fakültesi Dergisi, $\quad 1(2) . \quad$ https://dergipark.org.tr/en/download/article-file/161013 adresinden erişilmiştir.

Glickman, C. D., Gordon, S. P., and Ross-Gordon, J. M. (2004). Action research: The school as the center of inquiry. Carl D. Glikman, Stephen P. Gordon ve Jovita M. Ross-Gordon (Ed.) In Supervision and instructional leadership: A developmental approach, (ss. 304-351), Boston: Pearson.

Goe, L., and Stickler, L. M. (2008). Teacher quality and student achievement: Making the most of recent research. TQ research \& policy brief. National comprehensive center for teacher quality, 1- 21, Washington DC. Retrieved from https://files.eric.ed.gov/fulltext/ED520769.pdf

Güçlü, N. (2004). Öğretmenlik mesleğine başlarken yeni öğretmenlerin örgütsel sosyalleşmeleri (1. Bask1). S. Şule Erçetin. (Ed.), İlk günden başöğretmenliğe içinde (ss.15-36). Ankara: Asil Yayıncılık.

Hamarat, F. (2002). Illköğretimde okul yöneticilerinin aday öğretmenleri işbaşında yetiştirmedeki rolleri ve yetişstirme uygulamaları. (Yayınlanmamış yüksek lisans tezi). https://tez.yok.gov.tr adresinden erişilmiştir (Tez No.117629).

Heick, T. (2018). The 6 stages of a teaching career. Retrieved from https://www.teachthought.com/pedagogy/6-stages-teaching-career/ 
Huberman, M. A. (1989). The professional life cycle of teachers. Teachers College Record, 91(1), 31-57.

Hong, J. Y. (2010). Pre-service and beginning teachers' professional identity and its relation to dropping out of the profession. Teaching and Teacher Education, 26, 1530-1543. doi: 10.1016/j.tate.2010.06.003

İlyasoğlu, A. (2006). Yakın dönemde tarihe ilginin farklılaşması sürecinde sözlü tarih alanının Türkiye'deki gelişimine bir bakış. Aynur İlyasoğlu ve Gülay Kayacan (Ed.). Kuşaklar deneyimler tanıklkklar içinde, (ss. 15-22), İstanbul: Tarih Vakfi.

Johnston, M. (2002). In the deep heart's core. New York, NY: Grove.

Kane, P. (Ed.). (1991). My first year as a teacher. New York, NY: Penguin.

Kaplan, E. U. (2015). Okul öncesi öğretmenlerinin yönetim ile yaşadığı sorunlar ve çözüm önerileri. Yaşadıkça Eğitim Dergisi, 29(1), 49-64. http://journals.iku.edu.tr/yed/index.php/yed/article/view/38/22 adresinden erişilmiştir.

Kıcır, B. (2010). Üniversite son sınıf ögrencilerinde işsizlik kaygısı: Psikolojik etmenler açısından bir inceleme. (Yayınlanmamış yüksek lisans tezi). https://tez.yok.gov.tr adresinden erişilmiştir (Tez No.265680).

Kol, S. (2011). Erken çocuklukta bilişsel gelişim ve dil gelişimi. Sakarya Üniversitesi Eğitim Fakültesi Dergisi, 21, 1-21. https://dergipark.org.tr/en/download/articlefile/115636 adresinden erişilmiş̧ir.

Korkmaz, S. (1999). Göreve yeni başlayan ögretmenlerin mesleğe uyum sorunları. (Yayınlanmamış yüksek lisans tezi). https://tez.yok.gov.tr adresinden erişilmiştir (Tez No.82298).

Korkmaz, İ., Saban, A. ve Akbaşlı, S. (2004). Göreve yeni başlayan sınıf öğretmenlerinin karşılaştıkları güçlükler. Kuram ve Uygulamada Eğitim Yönetimi, 38, 266-277. https://dergipark.org.tr/en/download/article-file/108406 adresinden erişilmiştir.

Kozikoğlu, İ. ve Senemoğlu, N. (2018). Mesleğe yeni başlayan öğretmenlerin karşılaştıkları güçlükler: Nitel bir çözümleme. Eğitimde Nitel Araştırmalar Dergisi, - Journal of Qualitative Research in Education, 6(3), 341-371. doi:10.14689/issn.2148-2624.1.6c3s 16m

Kök, M., Küçükoğlu, A., Tuğluk, M. N. ve Koçyiğit, S. (2007). Okul öncesi eğitiminin sorunlarına ilişkin öğretmen görüşleri (Erzurum ili örneği). Atatürk Üniversitesi Kazım Karabekir Eğitim Fakültesi Dergisi, 16, 160-171. https://dergipark.org.tr/en/download/article-file/31579 adresinden erişilmiş̧tir.

Kösterelioğlu İ. ve Kösterelioğlu M. A. (2008). Stajyer öğretmenlerin mesleki yeterliklerini kazanma düzeylerine ilişkin algıları. SAÜ Fen Edebiyat Dergisi, 10(2), 
http://www.fed.sakarya.edu.tr/arsiv/yayinlenmis_dergiler/2008_2/2008_2_13.p df adresinden erişilmiş̧ir.

Lortie, D. (1975). School teacher: A sociological study. Chicago, IL: University of Chicago Press.

MacKay, N., Quinlan, M. K., and Sommer, B. W. (2013). Community oral history toolkit: Volume 1. Walnut Creek, California: Left Coast.

Manuel, J., and Brindley, S. (2002, Eylül). On becoming an English teacher: Critical issues in the preparation, professional development, and retention of quality English teachers. European Educational Research Association Conference sunulan sözlü bildiri, Lisbon, Portugal.

Maskit, D. (2011). Teachers' attitudes toward pedagogical changes during various stages of professional development. Teaching and teacher education, 27(5), 851-860. doi: 10.1016/j.tate.2011.01.009

Meziroğlu, M. (2005). Sinıf ve branş öğretmenlerinin iş doyum düzeylerinin ölçülmesi (Zonguldak illi örneği). (Yayınlanmamış yüksek lisans tezi). https://tez.yok.gov.tr adresinden erişilmiştir (Tez No.187250).

McAdoo, H. (1980). Oral history as a primary resource in educational research. The Journal of Negro Education, 49(4), 414-422. doi:10.2307/2294917

Michie, G. (1999). Holler if you hear me: The education of a teacher and his students. New York, NY: Teachers College Press.

Miles, M. B., and Huberman, A. M. (2015). Nitel veri analizi: Genişletilmiş bir kaynak kitap. S. Akbaba Altun ve A. Ersoy (Çev. Ed). Ankara: Pegem Akademi.

Milli Eğitim Bakanlığı Öğretmen Yetiştirme ve Geliştirme Genel Müdürlüğü (2017). Öğretmenlik mesleği genel yeterlikleri. http://oygm.meb.gov.tr/meb_iys_dosyalar/2017_12/11115355_YYRETMENL YK_MESLEYY_GENEL_YETERLYKLERY.pdf adresinden erişilmiştir.

National Association for the Education of Young Children (2009). Developmentally appropriate practice in early childhood programs serving children from birth through age. Retrieved from https://www.naeyc.org/sites/default/files/globallyshared/downloads/PDFs/resources/position-statements/PSDAP.pdf

Organization for Economic Cooperation and Development (2006). Starting strong II: Early childhood education and care. Retrieved from http://www.oecd.org/education/school/37519079.pdf

Olson, M. R., and Osborne, J. W. (1991). Learning to teach: The first year. Teaching and Teacher Education, 7(4), 331-343. doi: 10.1016/0742-051X(91)90003-8

Özçakmak, H. ve Köroğlu, M. (2015). Türkçe öğretmeni adaylarının öğretmenlik mesleğine yönelik beklentileri. Ana Dili Eğitimi Dergisi, 3(4), 49-58. 
http://www.anadiliegitimi.com/tr/download/article-file/14936 adresinden erişilmiştir.

Öztürk, M. (2016). Köy ve kasabalarda görev yapan öğretmenlerin mesleğin ilk yılında yaşadıkları güçlükler. İlköğretim Online, 15(2), 378-390. http://ilkogretim-online.org.tr/index.php/io/article/view/1190 adresinden erişilmiştir.

Peisner-Feinberg, E. S., Burchinal, M. R., Clifford, R. M., Culkin, M. L., Howes, C., Kagan, S. L., and Yazejian, N. (2001). The relation of preschool child- care quality to children's cognitive and social development trajectories through second grade. Child Development, 72(5), 1537-1553. doi: 10.1111/14678624.00364

Pianta, R., Howes, C., Burchinal, M., Bryant, D., Clifford, R., Early, D., and Barbarin, O. (2005). Features of pre-kindergarten programs, classrooms, and teachers: Do they predict observed classroom quality and child-teacher interactions?. Applied developmental science, 9(3), 144-159. doi: 10.1207/s1532480xads0903_2

Roehrig, A. D., Pressley, M., and Talotta, D. A. (2002). Stories of beginning teachers: First-year challenges and beyond. Notre Dame, IN: Notre Dame Press.

Ruohotie-Lyhty, M. (2013). Struggling for a professional identity: Two newly qualified language teachers' identity narratives during the first years at work. Teaching and Teacher Education, 30, 120-129. doi:10.1016/j.tate.2012.11.002

Sabar, N. (2004). From heaven to reality through crisis: Novice teachers as migrants. Teaching and Teacher Education, 20(2), 145-161. doi: 10.1016/j.tate.2003.09.007

Sağlam, M. (2015). Primary school students' of 1980s' Turkey: Remembering their teachers. Educational Research and Reviews, 10 (6), 761-768. doi: 10.5897/ERR2014.1915

Sarı, M. H. ve Altun, Y. (2015). Göreve yeni başlayan sınıf öğretmenlerinin karşılaştıkları sorunlar. Hacettepe Üniversitesi Ĕgitim Fakültesi Dergisi, 30(1), 213-226. http://www.efdergi.hacettepe.edu.tr/yonetim/icerik/makaleler/31published.pdf adresinden erişilmiştir.

Say, M. (2005). Fen bilgisi öğretmenlerinin öz-yeterlik inanışları. (Yayınlanmamış yüksek lisans tezi). https://tez.yok.gov.tr adresinden erişilmiştir (Tez No.189037).

Senemoğlu, N. (2012). Gelişim, öğrenme ve öğretim. kuramdan uygulamaya. (21. Baskı). Ankara: Pegem Akademi Yayıncılık.

Schempp, P., Sparkes, A., and Templin, T. (1998). Identity and induction: Establishing the self in the first years of teaching. R. Lipka (Ed.), In Role of the 
self in teacher development (142-164). New York, NY: State University of New York Press.

Schweinhart, L. J., and Weikart, D. P. (1997). The High/Scope preschool curriculum comparison study through age 23. Early Childhood Research Quarterly, 12(2), 117-143. doi: 10.1016/S0885-2006(97)90009-0

Sünbül, A. M. (2005). Bir meslek olarak öğretmenlik (2. Bask1). Özcan Demirel ve Zeki Kaya (Eds), Öğretmenlik Mesleğine Giriş içinde (ss. 245-278). Ankara: Pegem A Yayıncılık.

Sylva, K., Taggart, B., Siraj-Blatchford, I., Totsika, V., Ereky-Stevens, K., Gilden, R., and Bell, D. (2007). Curricular quality and day-to-day learning activities in pre-school. International Journal of Early Years Education, 15(1), 49-65. doi:10.1080/09669760601106968

Şahin, İ. (2011). Prospective teachers' ideas about teacher recruitment and their professional future. Educational Sciences: Theory \& Practice, 11(3), 11791184. https://files.eric.ed.gov/fulltext/EJ936305.pdf adresinden erişilmiştir.

Thompson, P. (2017). The voice of the past: Oral history. Oxford: Oxford university press.

Tan, M. G. (2000). An oral history project with the children of the republic. IOHA Confrence, 1, 346-355.

Temizkan, M. (2008). Türkçe öğretmeni adaylarının öğretmenlik mesleğine yönelik tutumları üzerine bir araştırma. Türk Eğitim Bilimleri Dergisi, 6(3), 461-486. https://dergipark.org.tr/tr/download/article-file/256311 adresinden erişilmiştir.

Torres, A. (2012). "Hello, goodbye!": Exploring the phenomena of leaving early. Journal of Educational Change, 13(1), 117-154. doi: 10.1007/s10833-0119172-z

Tschannen-Moran, M., and Woolfolk Hoy, A. (2002, Nisan). The influence of resources and support on teachers' efficacy beliefs. Annual Meeting of the American Educational Research Association sözlü bildiri, New Orleans, LA.

Üstün, G., Dedekoç, Ş., Kavalalı, T., Öztürk, F., Sapçı, Y. ve Can, S. (2014). Üniversite son sınıf öğrencilerinin iş bulmaya ilişkin umutsuzluk düzeylerinin incelenmesi. Amasya Üniversitesi Eğitim Fakültesi Dergisi, 3(2), 200-221. https://dergipark.org.tr/en/download/article-file/19634 adresinden erişilmiştir.

Veenman, S. (1984). Perceived problems of beginning teachers. Review of Educational Research, 54(2), 143-178. doi: 10.3102/00346543054002143

Vonk, J. H. C. (1991). Becoming a Teacher, Brace Yourself. In H. W. Kam and R. Y. L. Wong (Eds.). Improving the Quality of the Teaching Profession. Singapore: The Institute of Education. pp. 63-81. 
Weber, R. P. (1990). Basic content analysis. London: Sage Puplications.

Wishard, A. G., Shivers, E. M., Howes, C., and Ritchie, S. (2003). Child care program and teacher practices: Associations with quality and children's experiences. Early Childhood Research Quarterly, 18(1), 65-103. doi: 10.1016/S0885-2006(03)00007-3

Yalçınkaya, M. (2002). Yeni öğretmen ve teftiş. Milli Eğitim Dergisi, 150, 153-154. https://dhgm.meb.gov.tr/yayimlar/dergiler/Milli_Egitim_Dergisi/153154/yalcinkaya.htm adresinden erişilmiştir.

Yıldırım, A. ve Şimşek, H. (2016). Sosyal bilimlerde nitel araştırma yöntemleri. Ankara: Seçkin.

Zembat, R. (2012). Okul öncesi öğretmenlerinin okul yöneticisi, meslektaşları ve aileler bağlamında algıladıkları çatışma durumlarının incelenmesi. Eğitim ve Bilim, 37(163), 203-215. http://egitimvebilim.ted.org.tr/index.php/EB/article/view/1114/348 adresinden erişilmiştir. 


\title{
The Narratives of Preschool Teachers Belonging to Their First Year Professional Experiences ${ }^{1}$
}

\begin{tabular}{cccc}
\hline ARTICLE TYPE & Received Date & Accepted Date & Published Date \\
Research Article & 02.18 .2020 & 04.10 .2021 & 05.06 .2021 \\
\hline İpek Özbay Karlıdă & iD ${ }^{2}$ ve Mehmet Sağlam iD ${ }^{3}$ \\
Yozgat Bozok University
\end{tabular}

\begin{abstract}
This research covers the pre-school teachers' narratives about the first years (1-3 years) of their professional lives. The study aims at finding out the remembrances about the problems the preschool teachers had faced, the strategies related to those problems they had developed to come over in the first years of their professional lives. The method of the study is oral history method. The data of the study consists of oral narratives compiled by semi-structured interviews. The study group of the research consists of 20 preschool teachers. The data were analyzed by content analysis method. As a result of the research, it was seen that the expectations of the teachers for the future in the last year of undergraduate education were to be assigned as a priority. It was understood that at the beginning of the first year of their professions, they experienced happiness, excitement and uneasiness, but also experienced disappointment, fear, stress and hopelessness. When the problems experienced by the teachers when they first started the profession were examined, it was seen that the problems they experienced were very diverse. Also, it was seen that while these various problems experienced by teachers were mostly related to the physical environment and teaching profession skills. When the discussions about the approach of teachers to combat these problems were examined, it was recognized that they had benefit mostly from their short-term teaching experiences. The contribution of teachers' professional experiences to their professional development in the first year was found to be particularly effective in communicating with parents.
\end{abstract}

Keywords: Preschool teachers, oral history, professional experiences, professional life, narrative

The Ethical Committee Approval: Since this research was conducted before 01.01.2020, it does not require an ethics committee decision.

${ }^{1}$ This research article was presented as an oral presentation at the VIth International Eurasian Educational Research Congress held at Ankara University between 19-22 June 2019.

${ }^{2}$ Corresponding Author: Ph.D, Faculty of Education, Department of Primary Education, Division of Early Childhood Education, e-mail: ipek.karlidag@bozok.edu.tr, https://orcid.org/0000-0002-0996-5496

${ }^{3}$ Assoc. Prof., Faculty of Education, Department of Educational Sciences, Division of Educational Programs and Teaching, e-mail: mehmet.saglam@bozok.edu.tr, https://orcid.org/0000-0002-7166-7393 


\section{Purpose and Significance}

Early childhood is one of the most important and critical periods of human life (Senemoğlu, 2012). In early childhood, the child shows a rapid development in terms of physical, emotional, social, cognitive and language development (Senemoglu, 2012; Kol, 2011). During this rapid developmental period, children are more open to external stimuli and more flexible in terms of behavior change and adaptation (Barrett, Cooper and Teoh, 2014). Therefore, the quality of education to be given to children in early childhood is one of the important environmental factors on child development.

It is seen that the school success, cognitive, language and social-emotional development competence of children attending pre-school institutions with high quality level are higher than the others (Barnett, 1995; Clarke-Stewart, 1992; PeisnerFeinberg et al., 2001; Schweinhart and Weikard, 1997; Sylva et al., 2007). When the effects of the quality of preschool education institutions on a child are considered, these variables that determine the quality of the preschool education institution must be appropriate for the development of the child (NAEYC, 2009). Teachers have a decisive role in providing quality service in preschool education institutions (Dağlığlu, 2012). Teacher competencies have a significant impact on the success of the learning process (Angrist and Lavy, 2001; Darling-Hammond, 2000; Goe and Stickler, 2008). In this respect, considering the characteristics of the teaching profession, teachers are expected to have some common characteristics.

Personal characteristics of teachers, their predisposition to the teaching profession and whether they chose this profession voluntarily appear as factors affecting their success in their professions (Demirel, 1995). Within the framework of the general competencies of the teaching profession, the university faculties of education, which assume the responsibility of teacher training, have an important function for the teacher to have these qualifications. Faculties of education are particularly effective in achieving, producing and transferring scientific knowledge to the teacher candidates. On the other hand, when the developed countries are examined in teacher education, it is seen that they tend to give more place to the practice as well as theoretical knowledge (Doyle, 1986; Garmon, 1993). In this case, the pre-service teachers need to integrate the theoretical knowledge with the practical application experiences in achieving the expected qualifications. On the other hand, pre-service teachers have the opportunity to integrate their theoretical knowledge with their professional experiences only when they start to work as teachers. Therefore, the professional experiences of the teachers regarding their first years in their professional lives appear as an important issue. In this study, the experiences of preschool teachers in the first years of their professional lives were examined.

\section{Method}

This research is a qualitative study and the method of which is oral history. Oral history is an alternative interdisciplinary historical approach that cares about the lifestyles of individuals, different segments of society, their socialization elements in 
historical studies and contributes to social history (İlyasoğlu, 2006; Thompson, 2017). This method has an important function in revealing the details of the lives of those excluded from the dominant historiography and making them a part of the historiography (Tan, 2000).

It is almost impossible to reach the educational experiences and professional experiences of students, teachers and parents who are the components of education in written documents. Oral history is an important tool in uncovering these experiences. Referring to the educational practices and experiences of these groups that have become memories as part of their educational experiences in studies provides significant data to the researchers (McAdoo, 1980; Sağlam, 2015). In this context, the oral history method was preferred because of being an effective tool to reveal the narratives of pre-school teachers about their first years of their professional lives.

Study Group. The study group of the study consists of 20 preschool teachers selected through purposive sampling. Two of them in the study group were male and 18 were female. The duration of professional experience of preschool teachers in the study group varies between 4 and 20 years.

Data Collection Tool. The data of the study were obtained via interviews with the preschool teachers. The interviews were conducted by semi-structured questions developed by researchers. The questions were designed to reveal the experiences of teachers in their first years (1- 3 years) in their professional lives. All of the interviews took place in a suitable room where the teachers work. Before the interview, each participant was informed about the research subject, aims, and their rights in the research process. After this notification, the participant's confirmation about voluntarily participated in this interview was obtained. Data collection process was completed between 17 December 2018 and 10 January 2019.

Data Analysis. The content analysis method was used in the analysis of the data obtained in the study. Due to this, the audio recordings taken during the interviews with the participants were converted into text. Then, each of the texts was carefully examined and organized into six sub-categories. Validity and reliability in the evaluation of the texts have been ensured by analyzing the researchers based on consensus (Creswell and Miller, 2000). In order to materialize it, the researchers first examined the interview texts individually and formed their own codes. After that, the two researchers came together and compared the codes, questioned them and simplified the codes by using the related literature.

\section{Results}

According to the research findings related to the first sub-problem of the study; at the end of the undergraduate years, it is seen that teachers mostly want to be appointed as a teacher and provide good quality education suitable for the development of children. In addition, enjoying doing his job, improving himself by doing a master's degree and playing an active role in seeing the necessary value of 
pre-school education are other expectations of the teachers before they start their profession.

Also, the research findings related to the second sub-problem of the research reveal that they have experienced the most feelings of happiness, excitement and uneasiness at the beginning of their first year. Some express feelings of frustration, fear, stress and hopelessness at the beginning of their first year. Moreover, the research findings related to the third sub-problem of the study reflect that in their first years they have faced various problems that were resulted from relations with colleagues, those of school administration, the physical environment and teaching professional skills.

When considering the findings in relation to the fourth sub-problem of the study, it is found out that they mostly have overcome the problems during their short-term teaching experiences. Additionally, the findings considered with the fifth sub-problem of the study, it is observed that some of the problems they have encountered in their first years have decreased and disappeared over time and some of them still have continued. Lastly, the findings which are relevant to the sixth sub-problem of the study display that their first years' professional experiences have resulted in establishing effective communication not only with the children but also with parents.

\section{Discussion and Suggestion}

As a result of the research, at the end of the undergraduate years, it is seen that teachers mostly want to be appointed as a teacher. When the related literature is examined, many studies supporting this finding of the study have been found. In one of the studies, it was stated that approximately $27 \%$ of the last year students of a university had had anxiety about finding a job (Gizir, 2005). The same situation was found in studies conducted with students from different universities and stating that the majority of students had been concerned about finding a job when they graduated (Dereli and Kabataş, 2009; Dursun and Aytaç, 2009; Kıcır, 2010). In some other studies, it is also found out that appointment anxiety has been the main source of stress for their future (Akpınar, 2013; Aslan, 2010; Üstün et al., 2014; Şahin, 2011).

When the emotions felt by preschool teachers at the beginning of their first year were examined, it was noticed that while they had experienced feelings of frustration, fear, stress and hopelessness, they also had felt happiness and excitement. RuohotieLyhty (2013) in her study of the teachers' narratives about their first years of professional lives reveals that the teachers have felt uneasiness, distrust, confusion, frustration and stress. In some other studies conducted on teachers' professional experiences, it is observed that teachers have had feelings such as anxiety, stress, frustration and inadequacy in various subjects in the first years (Ewing and Smith, 2003; Manuel and Brindley, 2002).

Another important finding obtained in the study is that preschool teachers had a range of problems when they started their profession. When these problems are examined; they have resulted from relations with colleagues, those of school 
administration, the physical environment and teaching professional skills. Considering the related literature, it is generally accepted that the first year of the teaching profession is the most difficult year of their teaching career (Fullan, 2007). It is also understood that they have some common problems and difficulties (Olson and Osborne, 1991; Veenman, 1984). Yalçınkaya (2002) claims that being inexperienced, inability to overcome professional responsibilities and difficulties in adapting to school and social and cultural environment are the most common problems teachers have encountered. Also, the teachers starting the profession often experience negative affect such as; frustration, doubt, anxiety and guilt (Roehrig, Pressley and Talotta, 2002).

The studies reflecting the problems the teachers reveal that inadequate understanding of the different developmental needs of children, lack of materials and resources, difficulty in establishing an individualized education program, inadequacy in working with bilingual students, low level of classroom management, low salary, difficulties in establishing positive interactions with parents and colleagues are the problems that teachers experienced in their first years (Fantilli and McDougall, 2009, Kozikoğlu and Senemoğlu, 2018). Additionally, not being valued adequately by the society and having difficulties in dealing with the students coming from different cultural environment seem to be some other problems the teachers have confronted with (Ewing and Smith, 2003; Güçlü, 2004; Johnston, 2002; Kozikoğlu and Senemoğlu, 2018; Sünbül, 2005; Veenman, 1984). In the present study, it is grasped that the problems expressed by the teachers are similar to the research findings obtained from other studies. The source of having similar problems for the teachers can be considered being inexperienced during their first years' teaching profession.

When the ways of struggling against the problems they experienced in their first years' teaching experience are examined, it is seen that the teachers have mostly benefited from their short-term teaching experiences. Furthermore, it is noticed that teachers have made use of the experiences of their colleagues, theoretical knowledge they acquired during their undergraduate years, the guidance of faculty members from whom they had already taken courses during their undergraduate education, as well as, seminars, conferences, in-service training and courses. Taking into consideration the related literature, it is understood that the teachers have felt more equipped in terms of their professional competence because of gaining experience in their professional lives (Gençtürk and Memiş, 2010; Meziroğlu, 2005; Say, 2005; Tan, 2000). In this context, it is an expected result that teachers should benefit from their own teaching experience in order to struggle with the problems they face. Besides, receiving support from a more experienced person in the related field is thought to be a critical factor in eliminating the problems in the first years of their teaching profession (Ewing and Smith, 2003). A teacher's support from an experienced teacher makes it easier for him to overcome the difficulties (Conderman and Stephens, 2000).

In addition, in the research, the changing situation of the problems during the time is examined and it is found out that the changing statues of them have been as 
"decreasing, disappearing" and "continuing" in their narratives. It is seen that the problems of teachers related to their teaching skills have mostly decreased and disappeared in time. Also, some other problems such as lack of family participation, inadequate interest of the primary education administration in preschool education and the idea that "preschool teacher can not be male" have disappeared in the course of time. It is known that the problems related to their teaching profession skills vanish throughout the time due to the fact that the professional competence of teachers develops (Gençtürk and Memiş, 2010). Furthermore, the problems like inappropriate physical conditions of the school building are considered to be continued ones owing to their presence being independent of teachers.

When these results of the research are taken into consideration, it can be ensured that the professional skills of the pre-service teachers have reached a better situation with the increase in teaching practices during their undergraduate education. As a result of this, pre-service teachers have better and higher self-esteem in their professional sense when they start to work as preschool teachers. It must be ensured that the physical conditions of schools are to be regulated in accordance with the regulations. Also, the supervision processes have to be more effective in accordance with the legal regulations. To reduce the specific number of problems the teachers face in general, more care is to be given to the pre-service training particularly to these specific problems. At the same time, it can be thought that creating a working environment aimed at providing professional satisfaction among teachers in order to provide relations that can increase professional efficiency will be effective in creating a positive school climate.

\section{The Ethical Committee Approval}

This research article was presented as an oral presentation at the VIth International Eurasian Educational Research Congress held at Ankara University between 19-22 June 2019, and since the approval of the ethics committee is not mandatory for the researches conducted on the specified date, this research does not have the ethics committee approval. 